
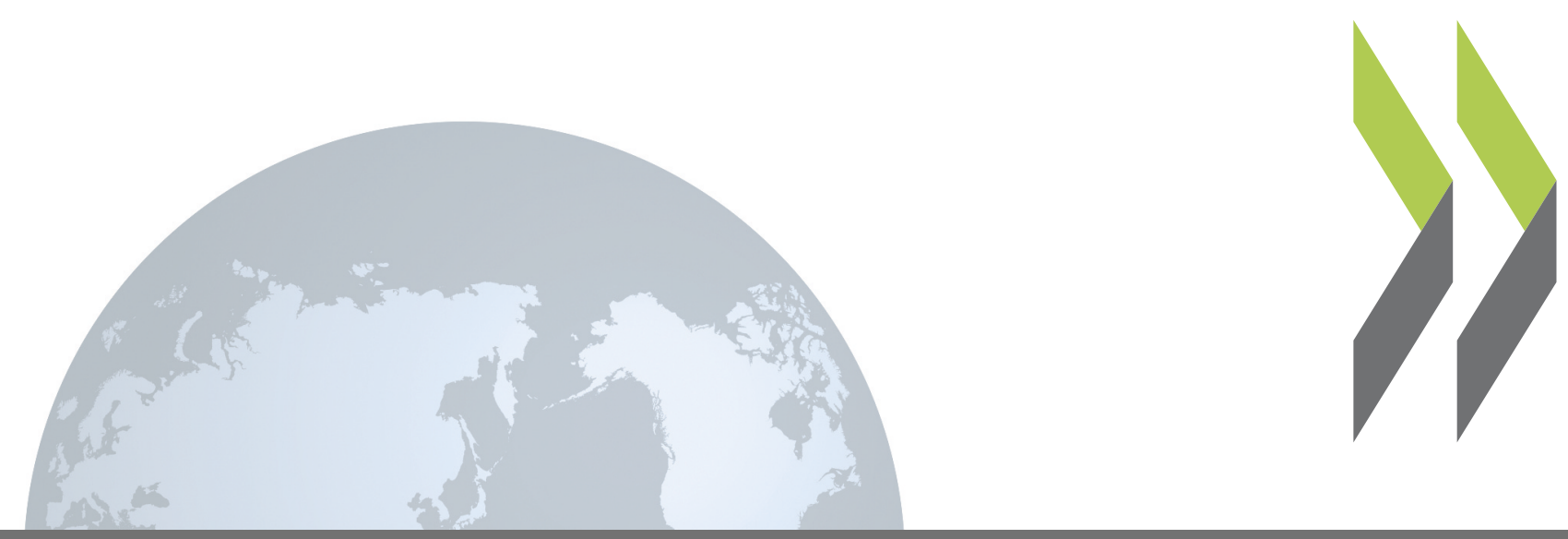

OECD Economics Department Working Papers No. 733

\author{
Pedal to the Metal: \\ Structural Reforms to Boost \\ Long-Term Growth \\ in Mexico and Spur \\ Recovery from the Crisis
}

\title{
David Haugh,
}

\section{Agustin Redonda}


Organisation de Coopération et de Développement Économiques

Organisation for Economic Co-operation and Development

03-Nov-2009

ECONOMICS DEPARTMENT

English - Or. English

PEDAL TO THE METAL: STRUCTURAL REFORMS TO BOOSTS LONG-TERM GROWTH IN MEXICO AND SPUR RECOVERY FROM THE CRISIS

ECONOMICS DEPARTMENT WORKING PAPER No. 733

By David Haugh and Agustin Redonda

All Economics Department Working Papers are available through the OECD internet website at www.oecd.org/WorkingPapers

JT03273384

Document complet disponible sur OLIS dans son format d'origine

Complete document available on OLIS in its original format 


\section{ABSTRACT/RESUMÉ \\ Pedal to the metal: Structural reforms to boost long-term growth in Mexico and spur recovery from the crisis}

While Mexico's growth performance has gradually improved over the past decades, its convergence toward OECD countries has been less rapid than in several other emerging markets. The recent significant reductions in import tariffs should help the economy take fuller advantage of trade and investment integration, which could be a relative strength for Mexico given its geographic location. Reforms introduced in the past two years, including those to promote competition and transparency in the financial sector and, to a lesser extent in telecommunications, will also stimulate the dynamism of the economy. Despite this progress, further reforms are needed to boost overall and within-sector productivity. Relative weaknesses in education, infrastructure, financial development, the rule of law, as well as a lack of competition come out in various studies as explaining why Mexico has not grown as fast as other countries. Focusing attention now on reforms in areas with rapid pay-offs such as improving competitiveness and infrastructure could yield double benefits in supporting the recovery from the current recession and longer-term growth. This can be achieved by increasing competition, especially in network industries, liberalizing further the foreign investment and trade regimes, and improving education coverage and trade-related infrastructure.

This Working Paper relates to the 2009 Economic Survey of Mexico.

(www.oecd.org/eco/surveys/Mexico)

JEL classification: F13; F43; L4; O4; O16; O47; O43

Key words: trade policy; economic growth; antitrust issues and policies; aggregate productivity; economic development; financial markets; institutions and growth; cross-country output convergence

\section{Pied au plancher : des réformes structurelles pour dynamiser la croissance à long terme au Mexique et accélérer la sortie de crise}

Ces dernières décennies, le Mexique a progressivement amélioré ses performances en matière de croissance, mais sa convergence vers les pays de l'OCDE a été beaucoup moins rapide que celle de plusieurs autres marchés émergents. Les récentes réductions substantielles des droits à l'importation devraient aider l'économie à profiter plus pleinement de l'intégration des échanges et des investissements, ce qui pourrait constituer un atout relatif pour le Mexique compte tenu de sa situation géographique. Les réformes lancées ces deux dernières années, notamment celles qui visent à promouvoir la concurrence et la transparence dans le secteur financier et, à un degré moindre, dans les télécommunications, stimuleront également le dynamisme de l'économie. En dépit de ces progrès, de nouvelles réformes s'imposent pour favoriser la productivité globale et sectorielle. Selon diverses études, si la croissance du Mexique n'a pas été aussi rapide que celle des autres pays, cela tient aux faiblesses relatives concernant l'éducation, le développement du secteur financier et l'Etat de droit, à quoi s'ajoute le manque de concurrence. Concentrer maintenant l'attention sur des réformes rapidement rentables - en améliorant, par exemple, la compétitivité et les infrastructures - pourrait générer un double effet positif : soutenir la reprise pour sortir de la récession actuelle et créer de la croissance à long terme. On peut y parvenir en développant la concurrence, notamment dans les industries de réseau, en libéralisant davantage le régime des investissements étrangers et des échanges commerciaux, et en améliorant la couverture de l'enseignement et les infrastructures liées au commerce.

Ce document de travail se rapporte à l'Etude économique de l'OCDE du Mexique 2009

(www.oecd.org/etudes/Mexique)

Classification JEL : F13 ; F43 ; L4 ; O4 ; O16 ; O47 ; O43

Mots clés : politique commerciale; croissance économique; politiques et mesures anti-trust; productivité agrégée; développement économique; marchés financiers et croissance; cadre institutionnel; convergence économique entre pays

Copyright OECD 2009

Application for permission to reproduce or translate all, or part of, this material should be made to: Head of Publications Service, OECD, 2 rue André-Pascal, 75775 Paris cedex 16, France. 


\section{TABLE OF CONTENTS}

Pedal to the metal: Structural reforms to boost long-term growth and spur recovery from the crisis in

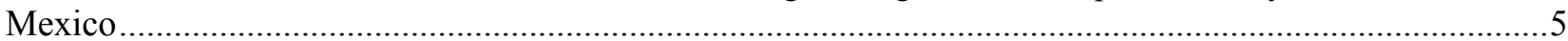

Mexico's growth performance compared - some salient facts .............................................................6

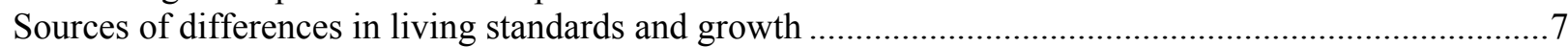

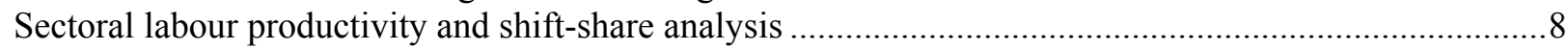

Mexico's convergence with high-income countries has been slow .......................................................10

What do models tell about factors that hold back Mexico's growth rate? ...............................................14

Where to from here? Policy priorities for lifting growth further .........................................................20

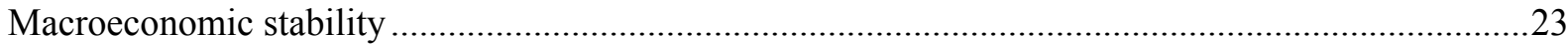

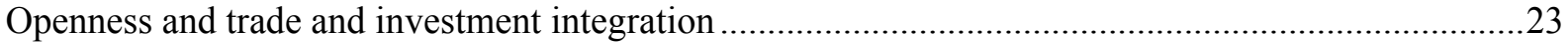

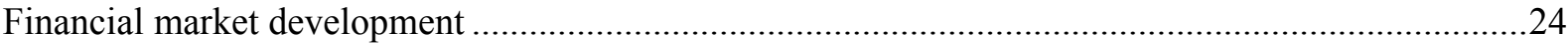

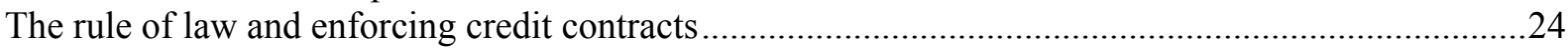

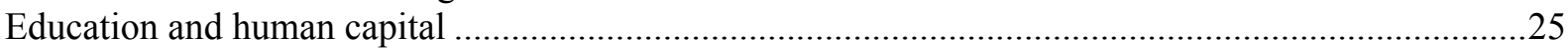

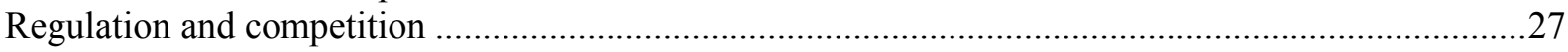

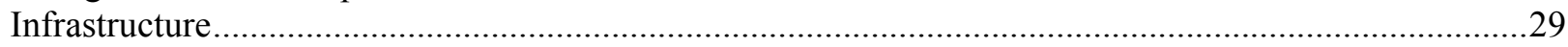

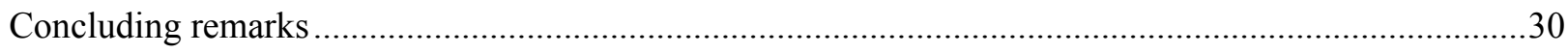

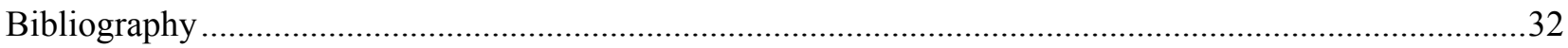

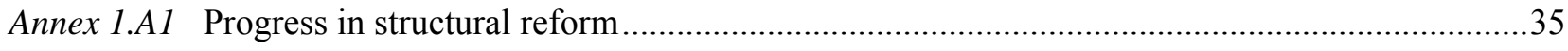

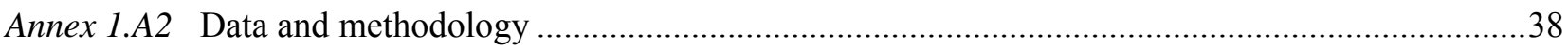

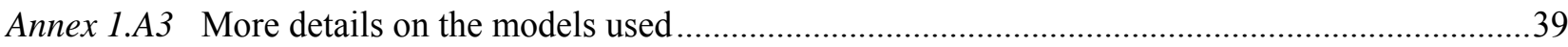

\section{Tables}

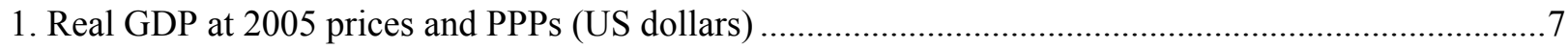

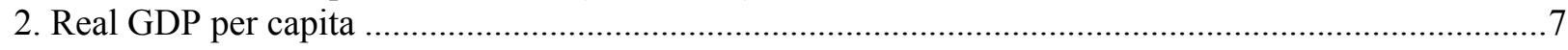

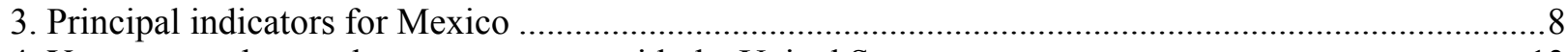

4. Years to reach complete convergence with the United States ..........................................................13

\section{Figures}

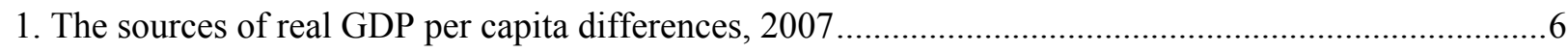

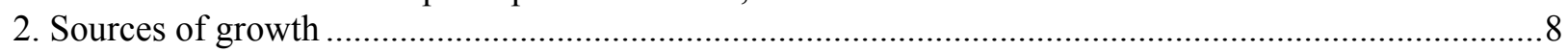

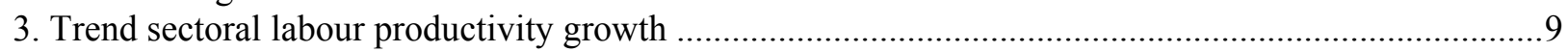

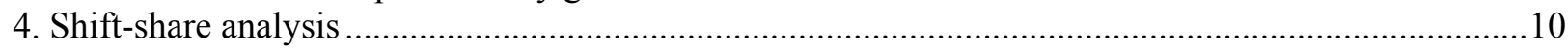

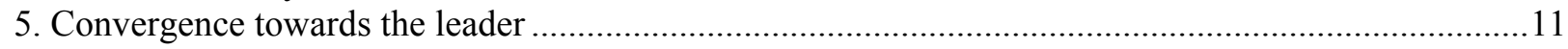

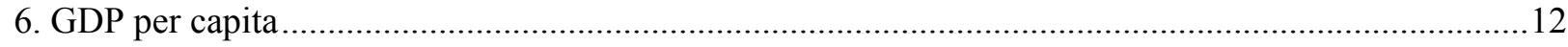

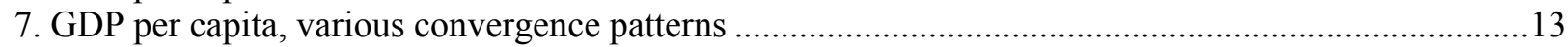

8. Annual average GDP per capita growth performance ….................................................................15

9. Relative contribution of macroeconomic stabilisation policies to GDP per capita growth ...................16

10. Relative contribution of structural policies to GDP per capita growth .............................................16

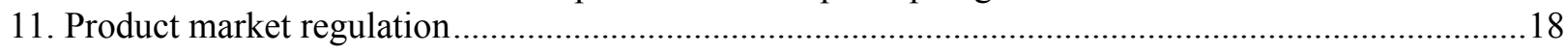

12. Knock-on effects of product market regulation at the sector level compared ...................................19 


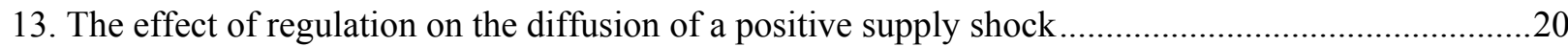

14. Simulated convergence of labour productivity towards the United States .......................................21

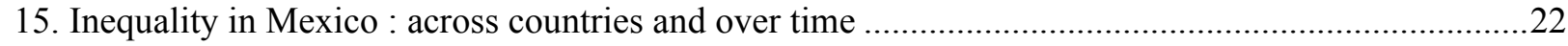

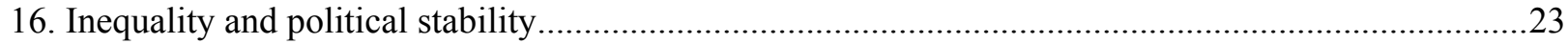

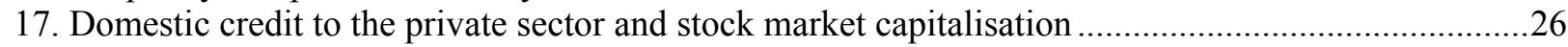

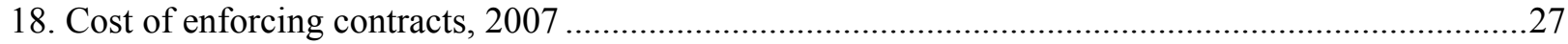

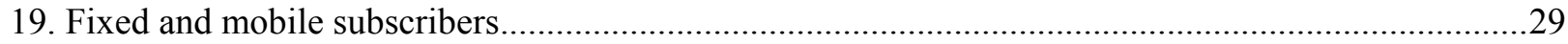

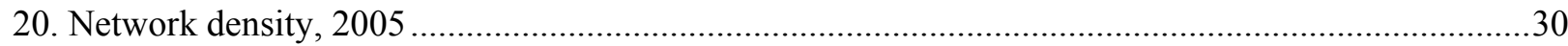

\section{Boxes}

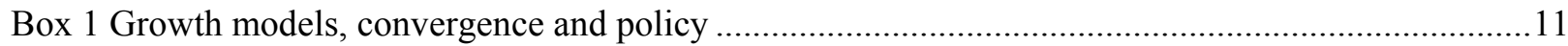

Box 2 Growth and Inequality - lessons for Mexico from the current literature.......................................22

Box 3. Reducing unnecessary restraints on competition using the competition assessment toolkit..........28

Box 4 Policy recommendations for boosting growth and spurring economic recovery ...........................31 
ECO/WKP(2009)74

\title{
Pedal to the metal: Structural reforms to boost long-term growth and spur recovery from the crisis in Mexico
}

\author{
By David Haugh and Agustin Redonda ${ }^{1}$
}

1. Mexico's growth record has not been stellar over the past decades and, as a result, living standards are not converging towards the higher income levels enjoyed elsewhere. The historical experience of Japan, for example, suggests that the challenge of catching-up can be met and have farreaching positive consequences. In 1950 Mexico and Japan had approximately the same level of GDP per capita. In the subsequent 40 years Mexico continued its relative decline vis-a-vis the United States contributing to the large gap in living standards between the two countries (Figure 1), while Japan enjoyed sustained growth and achieved one of the highest standards of living in the world. There have nonetheless been some improvements towards raising growth more recently in Mexico. Although growth of GDP per capita remains low compared to other dynamic emerging markets, it is now around $2 \%$ per annum, close to the OECD average and a vast improvement from stagnation in the late 1980s in the aftermath of the Latin American debt crisis. Instrumental to this have been reforms to open the economy to greater trade and investment and the establishment of macroeconomic stability. Implementing growth- friendly reforms would improve long-term prospects and could help in recovering from the crisis. In particular, measures such as competitively priced telecommunications services, adequate transport infrastructure, improving education outcomes and a more attractive climate for foreign investment would boost competitiveness and sustain demand. Greater competition would also contain price pressures and increase purchasing power over time.

2. This chapter discusses Mexico's growth performance and policy reforms to improve it. The first section compares the growth performance with that of other countries. In the second section, the sources of growth are examined with a view to identifying the causes of structural weaknesses (see Annex 1.A2 for data sources). The chapter ends by highlighting the structural policy areas that Mexico should address to shift to a higher growth path and sustain recovery and demand in both the short run and longer term.

1. The paper was originally produced for the 2009 OECD Economic Survey of Mexico, published in July 2009 under the authority of the Economic and Development review Committee of the OECD. We would like to thank, without implicating, Andrew Dean, Robert Ford, Patrick Lenain, Piritta Sorsa for comments on this paper and Pablo Fajnzylber for supplying the dataset from Loayza et al. (2005). All remaining errors are our responsibility. We are also grateful to Roselyne Jamin for research assistance and to Pascal Halim and Heloise Wickramanayake for editorial assistance. 
Figure 1. The sources of real GDP per capita differences, 2007

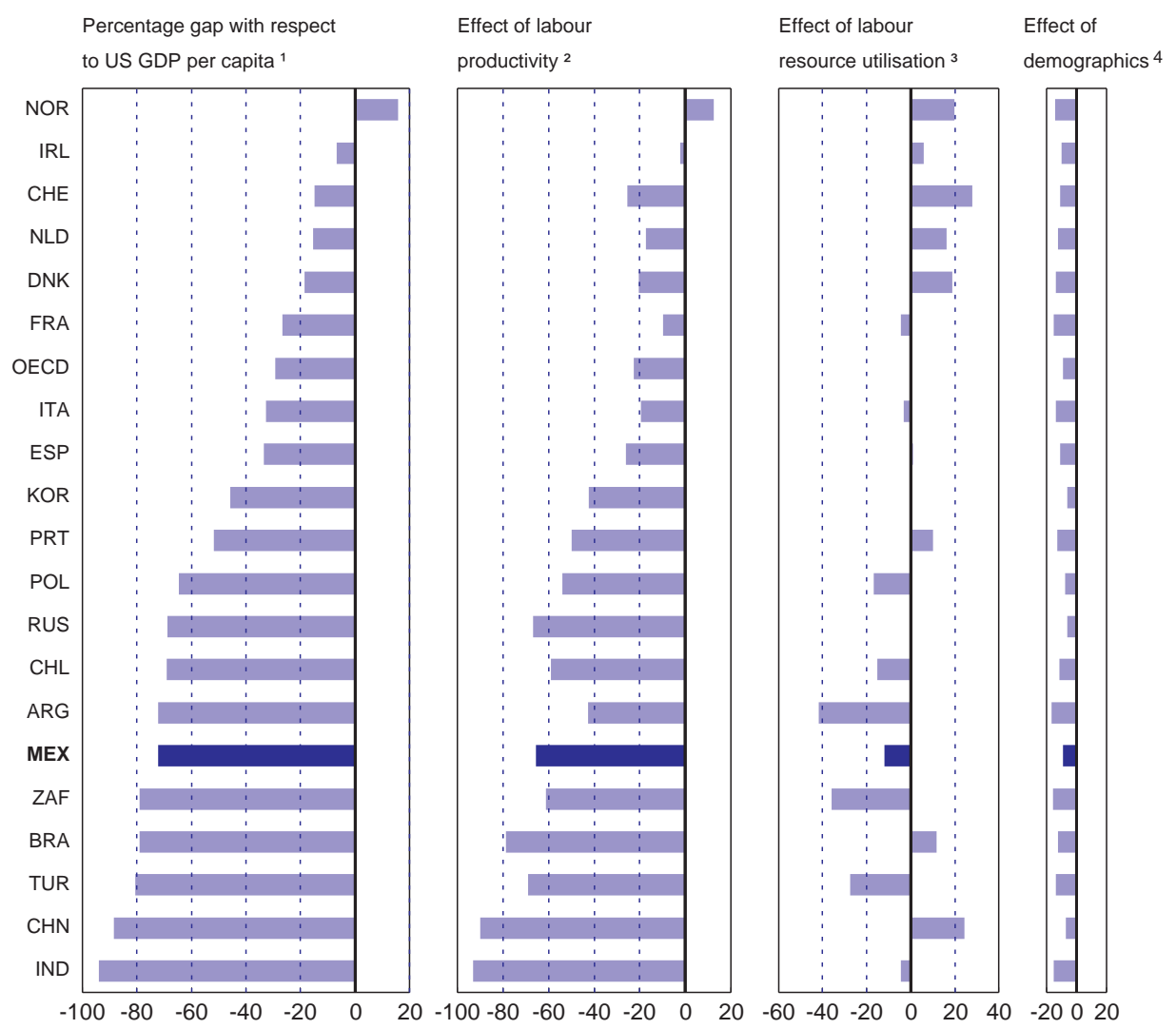

1. Based on 2005 purchasing power parities (PPPs).

2. Labour productivity is measured as GDP per person employed.

3. Labour resource utilisation is measured as the ratio of those employed to the persons of working age.

4. Measures the change in the ratio of persons of working age (15-64 years) to the total population.

Source: OECD, National Accounts; World Bank, WDI; International Monetary Fund, WEO; United Nations, UNSD.

\section{Mexico's growth performance compared - some salient facts}

3. Mexico's GDP growth has been low among emerging markets (Table 1). ${ }^{2}$ Together with Brazil, South Africa and Russia (a special case however due to the collapse of the planned economy) Mexico grew at rates around or below those observed on average in the OECD over the past two decades. By contrast, the better-performing emerging markets - Chile, China, India and Turkey - have grown rapidly during the whole period ranging from about $4 \%$ on average for Turkey to a spectacular $10 \%$ for China. Looking at the two decades separately shows that, while higher-income countries recorded a slow-down in their activity between the sub-periods, all the emerging countries (except Chile) increased their real GDP growth rates.

2. Mexico's growth record should be compared to both OECD and emerging economies to get an appropriate benchmark in line with income levels. As a member of the OECD, Mexico's performance is regularly compared with the mostly higher-income members of the OECD. See, for example, Scarpetta, Bassanini, Pilat and Schreyer (2000). This section extends this analysis by comparing Mexico with a peer group of large emerging market economies (defined here as those "emerging" in the world economy through greater participation in world trade and investment flows) such as Brazil, Chile, China, India, Russia, South Africa, and Turkey. They can be better comparators than OECD countries as their level of GDP per capita and development issues faced are more similar to Mexico's. They are also, like Mexico, pursuing economic reforms designed to assist convergence with the higher-income OECD countries. 
Table 1. Real GDP at 2005 prices and PPPs (US dollars)

\begin{tabular}{lrr|ccc} 
& \multicolumn{2}{c|}{ In Millions } & \multicolumn{3}{c}{ Annual average growth rates } \\
\cline { 2 - 6 } & \multicolumn{1}{c}{1987} & 2007 & $1987-1997$ & $1997-2007$ & $1987-2007$ \\
\hline USA & $7,173,680$ & $13,016,677$ & 3.13 & 2.91 & 3.02 \\
OECD average & 705,788 & $1,198,673$ & 2.74 & 2.62 & 2.68 \\
Brazil & $1,034,218$ & $1,716,542$ & 2.17 & 2.97 & 2.57 \\
Chile & 74,146 & 221,005 & 6.72 & 4.52 & 5.61 \\
China & $1,005,139$ & $6,704,554$ & 9.87 & 10.03 & 9.95 \\
India & 851,278 & $2,921,748$ & 5.41 & 7.31 & 6.36 \\
Mexico & $\mathbf{7 1 1 , 8 4 9}$ & $\mathbf{1 , 2 7 0 , 6 6 4}$ & $\mathbf{2 . 7 2}$ & $\mathbf{3 . 1 6}$ & $\mathbf{2 . 9 4}$ \\
Russia & $1,822,455$ & $1,917,612$ & -5.03 & 4.74 & 0.28 \\
S. Africa & 259,056 & 436,754 & 1.52 & 3.78 & 2.65 \\
Turkey & 275,081 & 621,864 & 3.89 & 4.43 & 4.16 \\
\hline
\end{tabular}

Source: OECD estimations. Where unavailable, World Bank (WDI), International Monetary Fund (WEO) and United Nations (UNSD)

4. Average GDP per capita growth rates over the last two decades are quite heterogeneous across the countries analyzed (Table 2). Over the past two decades, Mexico has grown more slowly than the United States, the OECD and the other emerging markets in the sample, except South Africa and Brazil (Table 2). This should have been a period of catch up. However, the trend over time is more encouraging GDP growth increased from $0.7 \%$ in the first decade to $1.9 \%$ in the second and closer to the OECD average.

Table 2. Real GDP per capita

\begin{tabular}{lrr|ccc} 
& \multicolumn{2}{c|}{$\begin{array}{c}\text { In 2005 PPPs (US } \\
\text { dollars) }\end{array}$} & \multicolumn{3}{c}{ Annual average growth rates } \\
& 1987 & \multicolumn{1}{c}{2007} & $1987-1997$ & $1997-$ & $1987-2007$ \\
\hline USA & 29,553 & 43,026 & 1.95 & 1.84 & 1.90 \\
OECD average & 20,800 & 30,410 & 1.92 & 1.92 & 1.92 \\
Brazil & 7,474 & 9,072 & 0.45 & 1.50 & 0.97 \\
Chile & 5,942 & 13,323 & 5.06 & 3.19 & 4.12 \\
China & 918 & 5,052 & 8.56 & 9.24 & 8.90 \\
India & 1,098 & 2,587 & 3.26 & 5.50 & 4.38 \\
Mexico & 9,250 & 11,983 & 0.70 & 1.91 & 1.30 \\
Russia & 10,199 & 13,482 & -4.39 & 5.16 & 1.88 \\
S. Africa & 7,492 & 9,096 & -0.53 & 2.50 & 0.97 \\
Turkey & 5,230 & 8,387 & 1.87 & 2.91 & 2.39 \\
\hline
\end{tabular}

Source: OECD estimations. Where unavailable, World Bank (WDI), International Monetary Fund (WEO) and United Nations (UNSD)

\section{Sources of differences in living standards and growth}

5. A comparison of sources of growth among emerging markets shows that weaker labour productivity is the principal reason accounting for Mexico's relatively weak performance. Labour productivity growth was slightly negative over the past 20 years in Mexico, while it was the main driver of growth in the better performing economies (Figure 2) 
Figure 2. Sources of growth

Average growth, 1987-2007

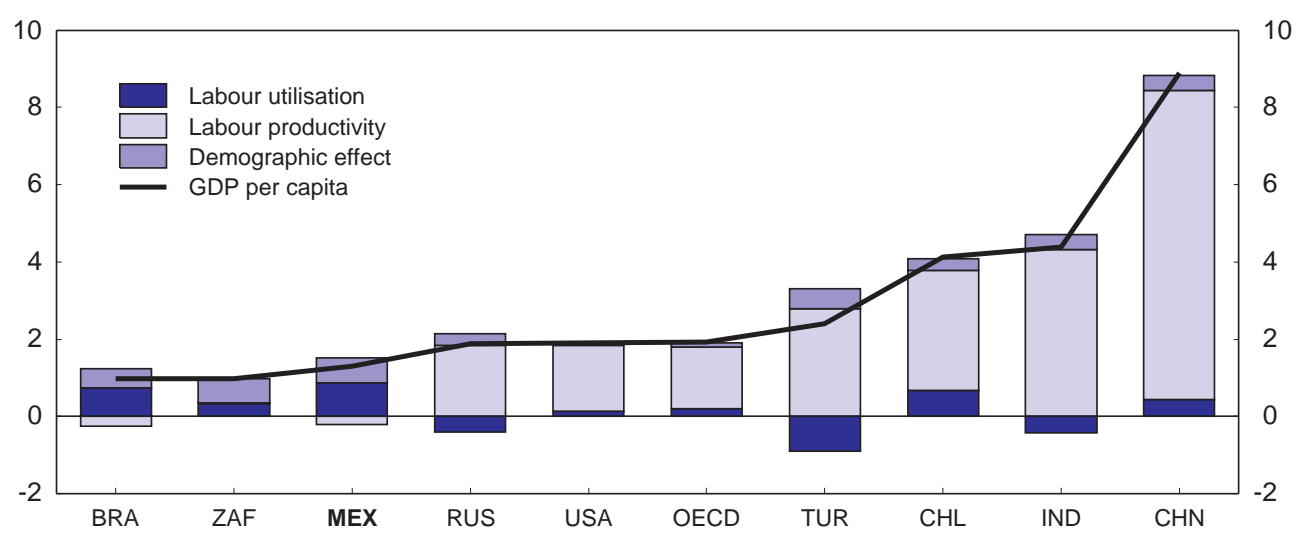

Source: OECD, National Accounts; World Bank, WDI; International Monetary Fund, WEO; United Nations, UNSD.

6. Breaking down Mexico's performance further into 5-year periods reveals a more encouraging story, as productivity growth has increased continuously from each 5-year period to the next. Per capita GDP trend growth has been close to the OECD average during the last 5-year period (around $2 \%$ per annum), although it remained well below that in better performing emerging markets. The acceleration in labour productivity explains the increasing GDP per capita growth rate over time (Table 3).

Table 3. Mexico: Sources of growth over time

\begin{tabular}{lcccc}
\hline \multicolumn{1}{c}{ Mexico } & $1987-1992$ & $1992-1997$ & $1997-2002$ & $2002-2007$ \\
\hline GDP & 2.44 & 2.99 & 3.16 & 3.16 \\
GDP per capita & 0.25 & 1.15 & 1.76 & 2.06 \\
Labour Productivity & -2.03 & -0.75 & 0.82 & 1.11 \\
Labour Utilisation & 1.73 & 1.32 & 0.24 & 0.21 \\
Demographics & 0.59 & 0.59 & 0.68 & 0.73 \\
\hline
\end{tabular}

Source: OECD estimations. Where unavailable, World Bank (WDI) and International Monetary Fund (WEO) and United Nations

\section{Sectoral labour productivity and shift-share analysis}

7. A breakdown by industry shows that the poor performance was broad based. ${ }^{3}$ In Mexico, the weak relative performance of productivity applies to about $80 \%$ of total employment - in agriculture, manufacturing, wholesale and retail trade and government and social services (Figure 3a). ${ }^{4}$ Even in the latest five-year period when Mexico's relative aggregate performance was strongest, it still had lower growth in agriculture, manufacturing, wholesale and retail trade than in the higher income OECD countries. Mexico had also not fully closed the growth gap in utilities and government and social services with the fast growing emerging markets (Figure 3b).

3. Total and sectoral labour productivity in Mexico is compared with 3 groups of countries, slower growing emerging markets (Brazil and Venezuela), fast growing emerging markets (Chile, India, Korea, Malaysia, Thailand) and fast growing, high-income OECD countries (Australia, Finland, Ireland, United Kingdom, United States).

4. Data for emerging countries was sourced from the ten sector database available at the Groningen Growth and Development Centre and is downloadable at http://www.ggdc.net/dseries/10-sector.html. See Timmer and De Vires (2007). Data for the OECD countries was sourced from the EU Klems database, March 2008 release, and is downloadable from http://www.euklems.net/. See Timmer, O'Mahony \& van Ark (2007). 
Figure 3. Trend sectoral labour productivity growth

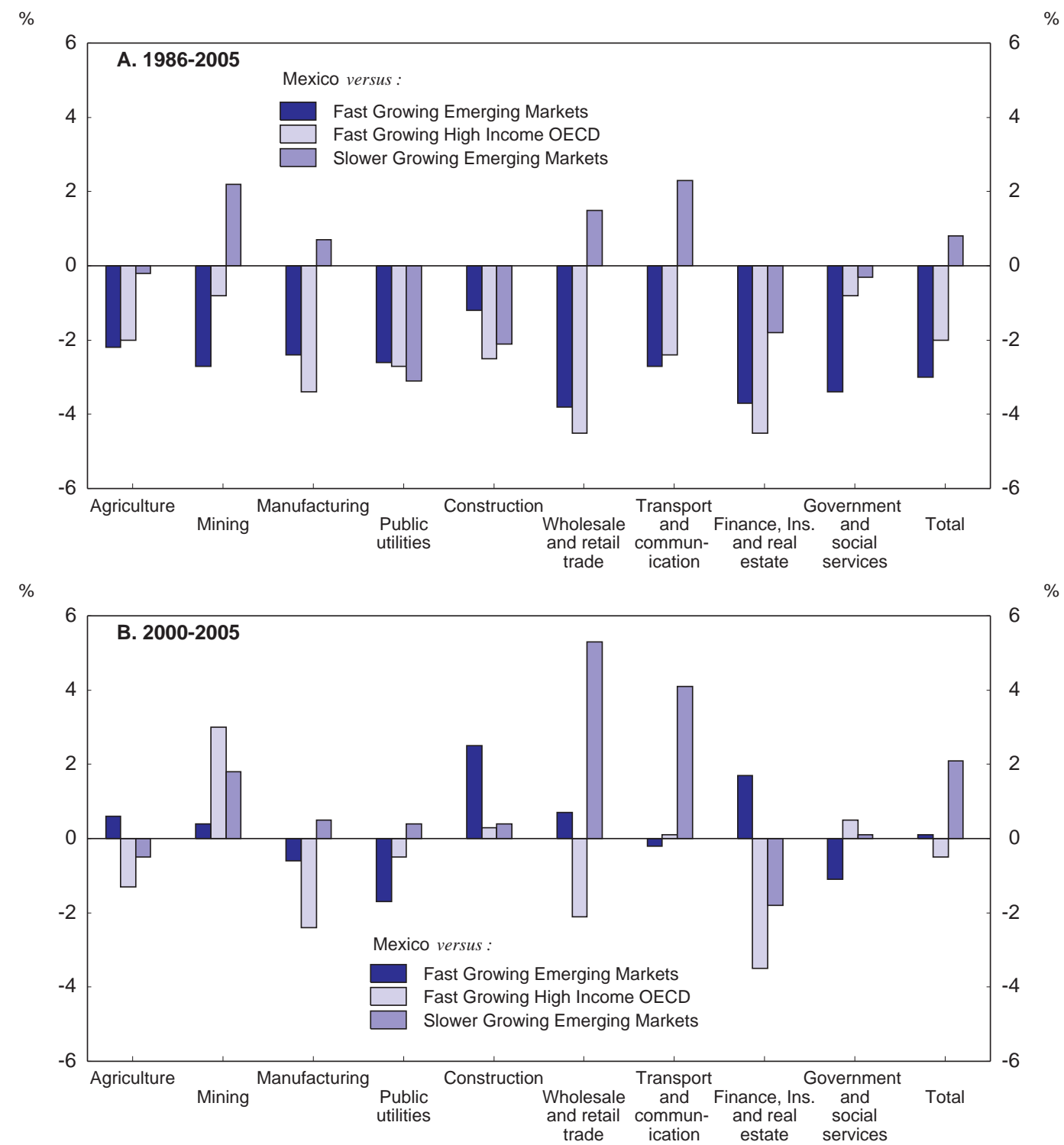

Source: OECD, based on EU KLEMS database; Groningen Growth and Development Center.

8. The total change in productivity can be further broken down into a "within-sector" effect (driven by technical change and capital accumulation), a "between-sector" effect (reallocation of labour resources between sectors), and a "cross-sector effect", that captures the interaction of productivity changes and employment shares. Between-sector effects dominated in Mexico until recently and accounted for the largest proportion of total labour productivity growth in the sample (Figure 4). This was mostly due to a large fall in agricultural employment, a sector with relatively low productivity. For the past 20 years within-sector productivity growth in Mexico was low compared to most other countries. Negative crosssector effects also largely offset the positive between-sector effect and account for a higher proportion of total productivity change compared to other countries. This occurred because sectors with relatively poor productivity growth, such as wholesale and retail trade and construction, gained employment share. 
Figure 4. Shift-share analysis

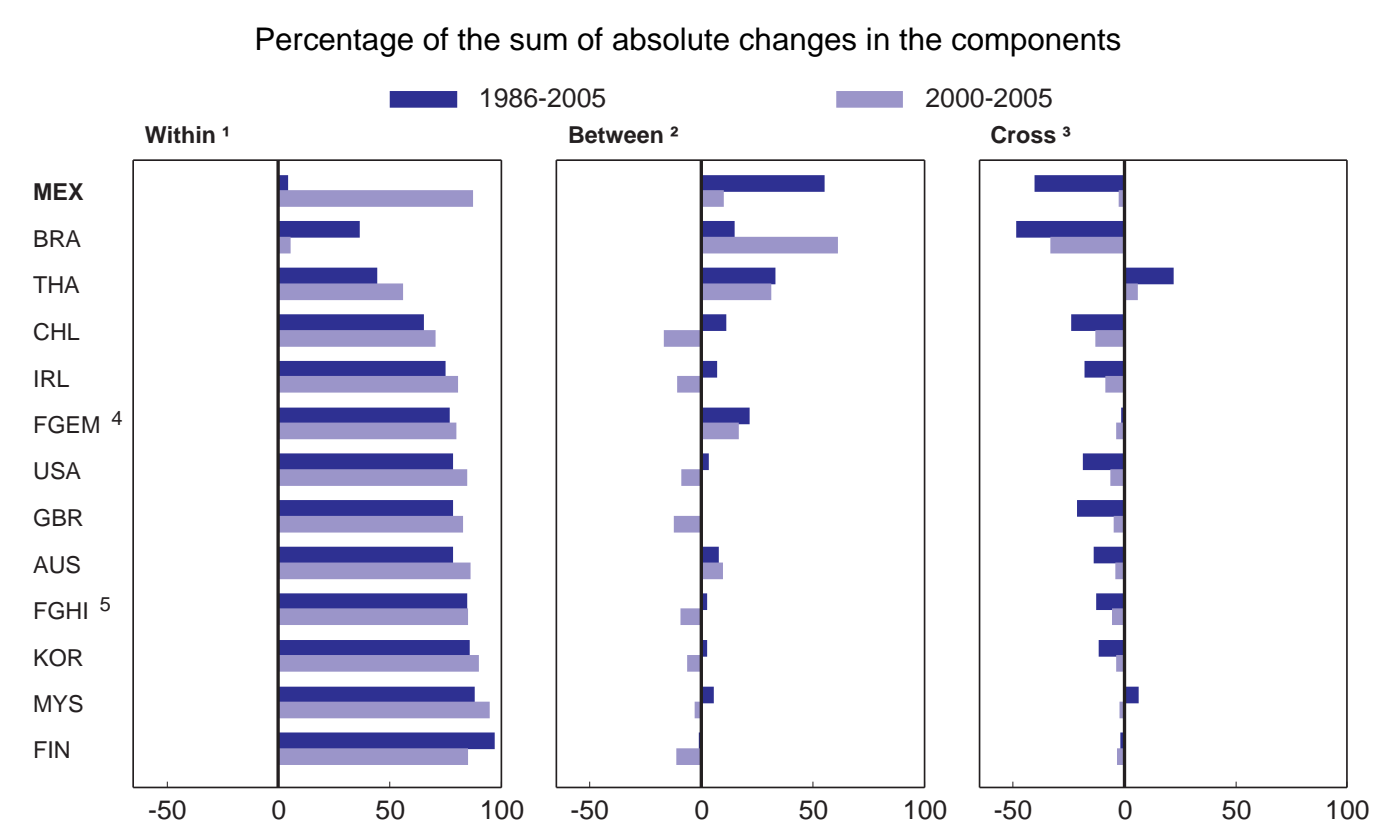

1. Within: within sector labour productivity.

2. Between: productivity growth due to reallocation of labour across sectors with different levels of productivity.

3. Cross: productivity growth from shifts of employment across sectors with different productivity growth rates.

4. FGEM for Fast Growing Emerging Markets.

5. FGHI for Fast Growing High Income OECD.

Source: OECD, based on EU KLEMS database.

9. In more recent years, productivity growth in Mexico has been mainly driven by within-sector productivity, a pattern more similar to other countries. Between-sector effects had a much smaller role as the economy matured and the rate of decline of agriculture's share of total employment eased. Small negative cross-sector effects were also much more in line with other countries. This occurred because the productivity gap between growth in slow growing Mexican sectors gaining employment share and fast growing sectors losing employment share (such as mining) closed.

10. The changing pattern suggests that Mexico's more recent sectoral pattern of productivity growth is becoming more similar to that of higher income countries. It is supported by productivity change at the industry level in contrast to the 1986-2000 period when productivity growth was mainly a product of labour migrating from agriculture to industry. Although labour productivity and GDP per capita growth rates have increased, they remain too low to allow rapid convergence with the high-income OECD countries. Within-sector productivity growth can be further boosted by capital, innovation and competition, which tend to be closely related to education, FDI and financial sector development.

\section{Mexico's convergence with high-income countries has been slow}

11. The slow pattern of Mexico's convergence towards higher-income levels is at odds with what is suggested by conventional economic theory. In principle, lower-income countries should grow faster than higher-income ones, due to diminishing returns to capital (Box 1). Empirically there is some evidence that this theory of convergence holds, but it is far from automatic (Figure 5). There are both converging and diverging countries within the OECD members and the selected emerging markets. However, the diversity of growth patterns between emerging countries is greater than for the high-income OECD economies, which tend to show more homogeneous growth paths. 


\section{Box 1 Growth models, convergence and policy}

Growth models tend to explain increases in output through the accumulation of inputs that make a contribution to the production process, and typically imply that public policy has a potentially strong role in influencing these processes.

A seminal model of economic growth, the augmented Solow-Swan model (Solow, 1956, 1957 and Swan, 1956), uses a neoclassical production function, $Y=F(K ; A L)$ where the marginal productivity is positive but decreasing for both factors, capital $(\mathrm{K})$ and labour $(\mathrm{L})$. Technical progress, A, grows at an exogenous and constant rate and increases labour productivity. In this model, capital, labour and the economy move towards a long-run steady state where a constant growth rate is determined by the population and technical progress growth rates. During the transition, the speed of convergence will decrease as the economy approaches its steady state because of diminishing marginal returns to capital. Richer countries closer to the steady state will grow slower than poorer ones. This convergence will only be absolute, i.e. to the same level of income per capita, if all countries have the same steady state. This in turn will only occur if the parameters that determine the steady state, population growth and rate of technical progress, are identical across countries. As these factors and, in particular, technical progress (representing here everything that augments labour productivity) are neither exogenous nor constant across countries convergence to similar income levels is not automatic. Public policy can have a large influence on technical progress as defined in the model and therefore significantly affect the convergence rates of countries.

The role of public policy is even clearer in the endogenous growth models. The most famous ones are the two-sector AK - or the Uzawa-Lucas - model (Uzawa (1961), Lucas (1988)) and Romer's model (1990). In these models diminishing returns to factor accumulation do not necessarily arise, and convergence is no longer a property of the growth process. Growth is driven in the long-run by factors such as human capital and research and development, where public policy has a strong potential influence.

Figure 5. Convergence towards the leader

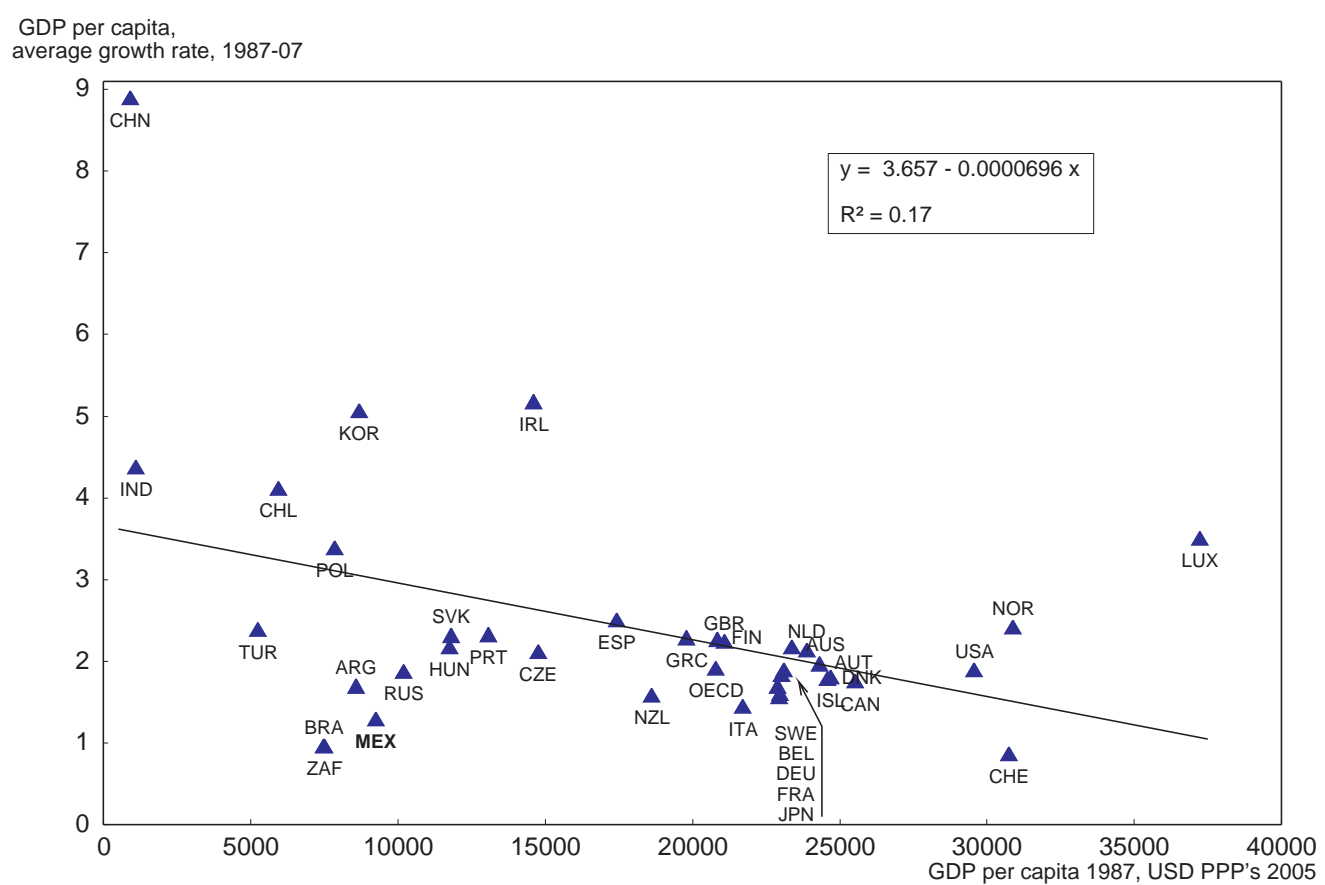

Source: OECD, National Accounts; World Bank, WDI; International Monetary Fund, WEO; United Nations, UNSD. 
12. The speed of convergence has also varied in history. The United States took a relatively short period of time to converge and surpass the $19^{\text {th }}$ century leader, the United Kingdom. By contrast, Japan and Germany diverged from the leader prior to the mid $20^{\text {th }}$ century and then converged rapidly after World War II, while Mexico continued to diverge (Figure 6).

Figure 6. GDP per capita

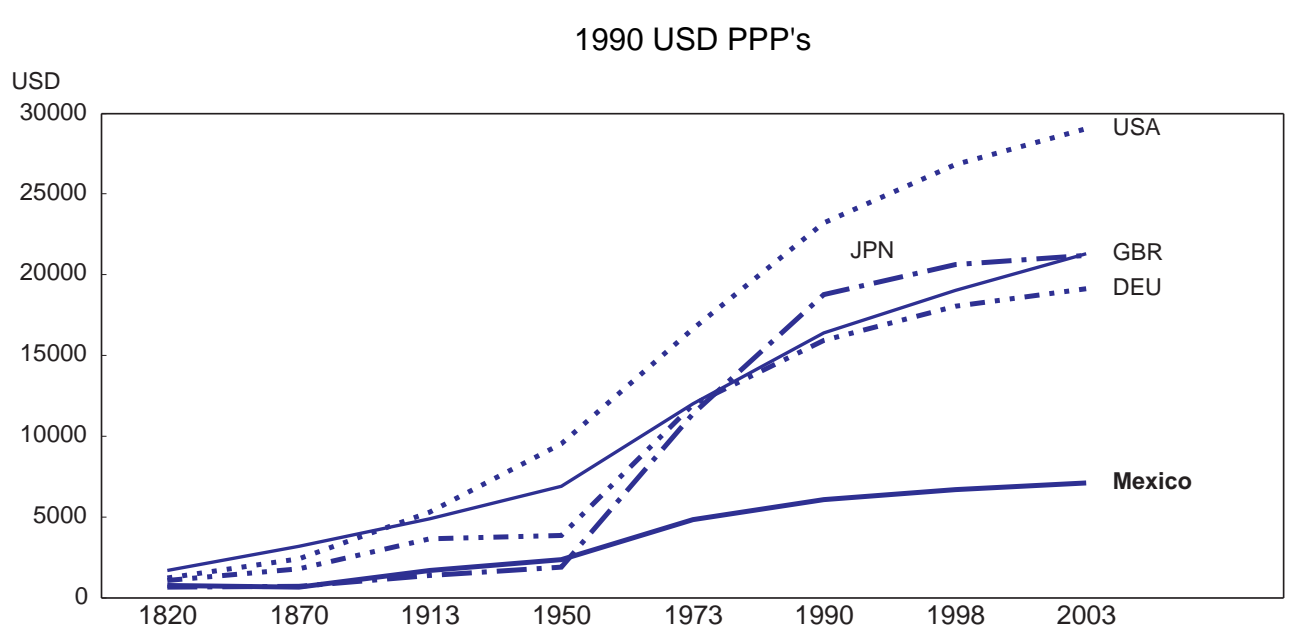

Source: Angus Madison (2003), The World Economy: Historical Statistics.

13. The speed of convergence has reflected differences in policies, saving and population growth rates. The latter influence convergence as they determine the steady state countries are converging to. Higher policy variance is related to the rate of technical progress, which tends to be important in emerging markets. Indeed, the catch up process should be seen as a potential one that has to be stimulated through sound policies rather than one that will happen naturally. Historical evidence suggests that divergent performance can endure a long time, which underlines the importance of ensuring the right policy mix that will lift growth.

14. To further emphasize the importance of growth-enhancing reforms, the speed of convergence towards living standards in the United States under different growth scenarios is examined (Table 4). This shows that if the speed of convergence observed for the past two decades continued, several emerging markets in the sample, including Mexico, would diverge from the United States or converge only slowly. The situation improves notably for Mexico if the last decade (which benefited from macroeconomic and trade policy reforms) is extrapolated - the country switches from divergence to convergence, although convergence would still take a very long time. Economic reform that generates extra growth can have large effects. A 1\% lift in Mexico's relative growth rate over the past decades would have moved Mexico from divergence to convergence at rates much faster than extrapolating even the 1997-2007 period. 
ECO/WKP(2009)74

Table 4. Years to reach complete convergence with the United States

\begin{tabular}{lccc|cccc}
\hline \multicolumn{3}{c}{ GDP per capita at 2005 PPPs (\$); (USA = 100) } & \multicolumn{4}{c}{ Years to reach convergence } \\
& 1987 & 1997 & 2007 & I & II & III & \\
\hline Russia & $\mathrm{n} / \mathrm{d}$ & 22.73 & 31.33 & -6511 & 36 & 121 & Russia \\
Mexico & $\mathbf{3 1 . 3 0}$ & $\mathbf{2 7 . 6 6}$ & $\mathbf{2 7 . 8 5}$ & $\mathbf{- 2 1 9}$ & $\mathbf{1 8 4 8}$ & $\mathbf{3 2 1}$ & Mexico \\
Brazil & 25.29 & 21.80 & 21.09 & -171 & -470 & 2029 & Brazil \\
S. Africa & 25.35 & 19.81 & 21.14 & -171 & 239 & 2008 & South Africa \\
China & 3.11 & 5.82 & 11.74 & 32 & 31 & 28 & China \\
Chile & 20.10 & 27.14 & 30.97 & 54 & 89 & 38 & Chile \\
India & 3.72 & 4.22 & 6.01 & 117 & 80 & 84 & India \\
Turkey & 17.70 & 17.55 & 19.49 & 338 & 156 & 112 & Turkey \\
OECD average & 70.38 & 70.13 & 70.68 & 1640 & 442 & 35 & OECD average \\
\hline
\end{tabular}

I. - Years to reach convergence (87-07 speed of convergence)

II. - Years to reach convergence (97-07 speed of convergence)

III. - Years to reach convergence (87-07 speed of convergence augmented by 1\%)

Note: Negative numbers indicate a diverging process

Source: OECD estimates. Where unavailable, World Bank (WDI), International Monetary Fund (WEO) and United Nations (UNSD)

15. Growth in Mexico has relied more on the accumulation of production factors than on rising productivity. Over the past twenty years, Mexico's growth pattern has been "extensive"-i.e. based on the growth of labour utilisation and changes in demographic structure (Figure 7). By contrast, the better performing countries, such as Chile, China, India, and Turkey exhibit an "intensive" growth path, with a greater reliance on high labour productivity growth rates.

Figure 7. GDP per capita, various convergence patterns

USA $2007=100$

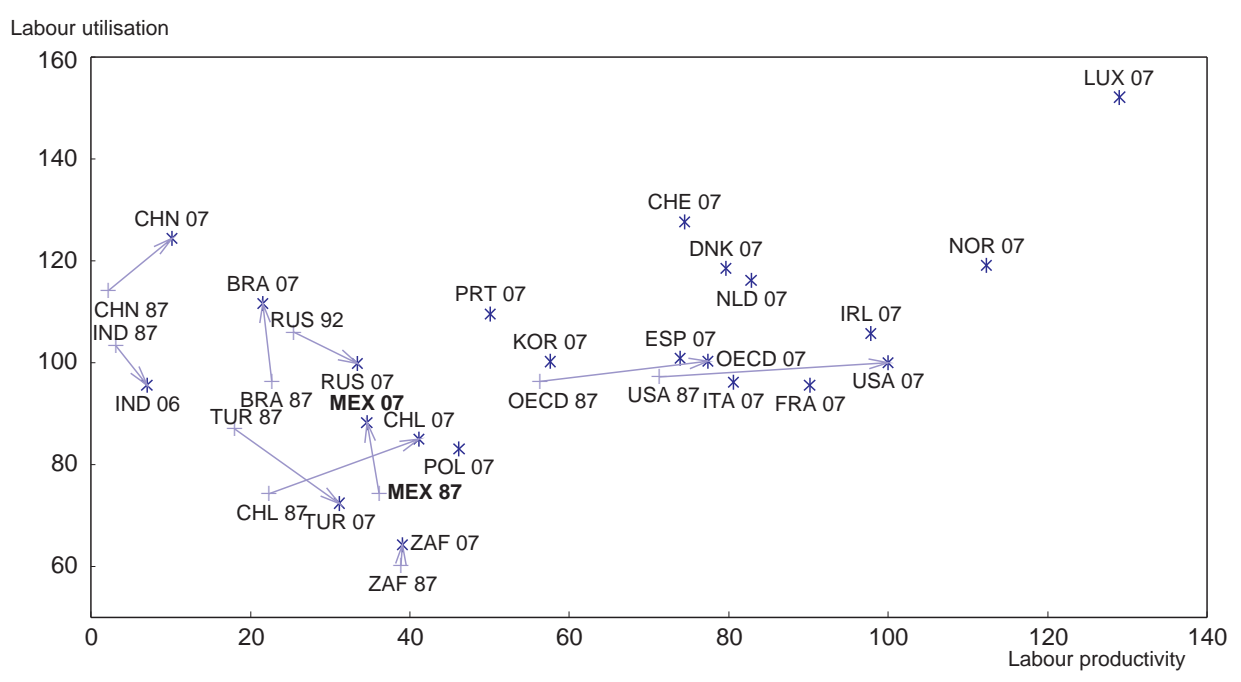

1. This figure shows the decomposition of GDP per capita into its two principal components, which are Labour Productivity (LU) and Labour Utilisation (LP). Countries in the left upper corner combine a high degree of LU with a low degree of LP. All contributions are expressed in relation to the USA's values in 1987. The chart also shows the change of positions between 1987 and 2007 for the selected countries (for Russia it shows changes between 1992 and 2007), the USA and the OECD.

Source: OECD, National Accounts; World Bank, WDI; International Monetary Fund, WEO; United Nations, UNSD.

16. Again, breaking down performance over time reveals a more positive story. Mexico's growth pattern has become more technology intensive. While labour productivity has been constantly increasing 
after the 1995 Tequila crisis, labour utilisation has actually been moving in the opposite direction from each 5-year period to the next (Table 3).

\section{What do models tell about factors that hold back Mexico's growth rate?}

17. Cross-country panel data models suggests that Mexico's slow catch up with the OECD countries was due historically to weak structural and macroeconomic policies. Mexico's growth performance is analyzed out of sample with several cross-country and panel data models (Annex 1.A3). ${ }^{5}$ They indicate that, all else equal, in view of the income gap (transitional convergence), Mexico's growth should have been $1.3 \%$ per annum higher than in the OECD countries between 1981 and 1999. In practice it was $1.9 \%$ lower (Figure 8). The positive convergence effect was more than offset by weaker structural and macroeconomic stabilisation policies. These are estimated to have reduced Mexican per capita growth by $1.8 \%$ in the structural case and between $0.7 \%$ and $1.8 \%$ in the macroeconomic policy case compared to the OECD group ${ }^{6}$. Country specific effects, external conditions and cyclical reversion played a minor role in explaining the differences over the whole sample period. However, cyclical reversion played a stronger role in boosting Mexican growth and explaining its relatively strong performance from 1996 to 1999 following the Tequila crisis.

5. These were chosen based on whether they included Mexico and emerging markets, policy variables and had accessible data. The Loayza, Fajnzylber and Calderón (2005) cross-country panel data model was used to compare Mexico with three groups with differing growth records--fast growing high income OECD ( the United States, United Kingdom, Australia, Finland, Ireland and Spain), fast growing emerging markets (China, India, Malaysia, Thailand, Korea, Turkey, Chile and Egypt), and slower growing emerging markets (Ecuador, Paraguay, Venezuela, South Africa, Argentina and Brazil).

6 For macroeconomic policies it depends on the magnitude of financial crisis effects used in the model. See Annex 1.A3 for details. 
Figure 8. Annual average GDP per capita growth performance

1981-1999

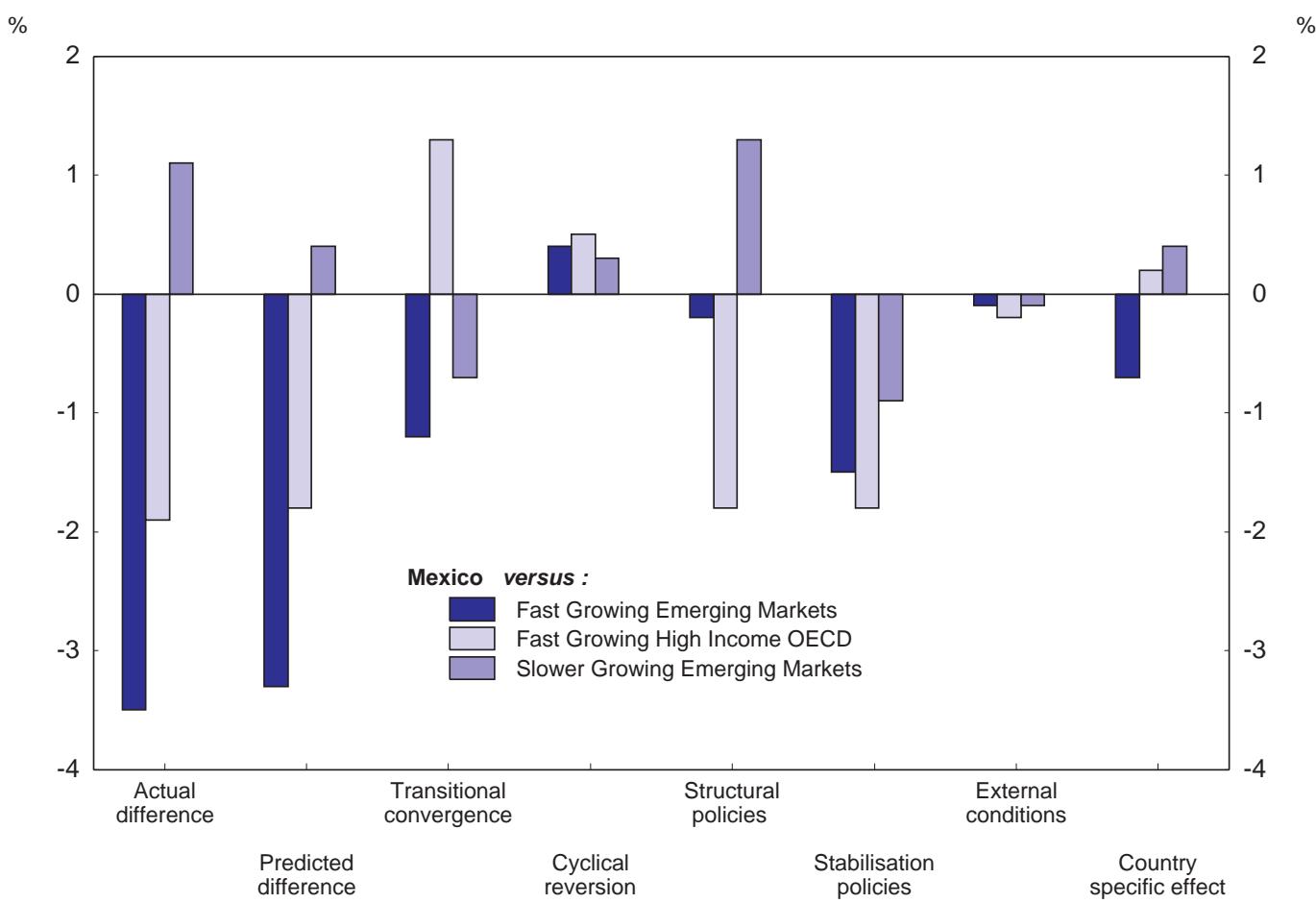

Source: OECD simulations using the Loayza, Fajnzylber and Calderón (2005) model.

18. From 1981 to 1999 , the growth difference with emerging markets was mainly due to weaker macroeconomic stabilization and transitional convergence effects. The former explain between $-0.4 \%$ and $-1.5 \%$ and the latter about $-1.0 \%$ of the difference in growth between Mexico and other emerging markets. When compared to the high-growth emerging markets, the results show that the main difference with Chile, Korea, and Malaysia was their superior structural policy setting. The difference with the lowerincome countries in this group, such as India, was their stronger convergence effect than in Mexico. When compared with the slower growing emerging markets, Mexico appears to have had stronger structural policy settings but weaker macroeconomic stabilisation and transitional convergence effects.

19. The comparison highlights the importance of both structural and macroeconomic policies for economic growth performance. Mexico's progress in this in recent years is confirmed by the data (Figure 9). Macroeconomic stabilisation started to contribute positively to growth since the mid-1990's relative to emerging markets and also had a smaller drag on catch-up with the fast growing high income OECD countries. This is further confirmed by extending the data to $2000-07 .^{7}$

7. The model estimates could not be extended beyond 1999 to other specifications as relevant data is not available for the emerging market group. 
Figure 9. Relative contribution of macroeconomic stabilisation policies to GDP per capita growth

$\%$

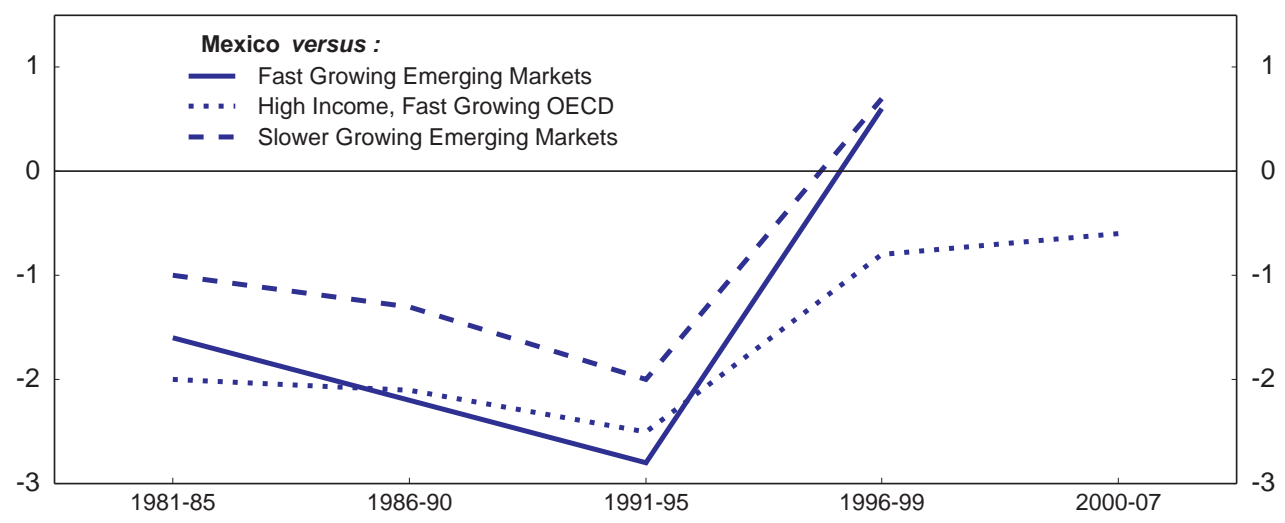

Source: OECD simulations using the Loayza, Fajnzylber and Calderón (2005) model.

20. The model suggests that more progress with structural reform remains key to faster growth. Lower inflation and the prevention of financial crises were important in raising the growth rate while slow progress with structural reform worked in the opposite direction. This suggests that if Mexico is to grow faster, it is especially in this area that improvements need to be made. Both higher-income, fast-growing OECD countries and the fast growing emerging markets have a stronger structural policy contribution to growth than Mexico. When the structural policy contribution is broken down further, Mexico's key weaknesses are in education, infrastructure and financial market development compared with both the high income OECD countries and the fast-growing emerging economies (Chile, Korea and Malaysia). Trade integration, governance and the size of government are less important (Figure 10) compared to the OECD group. The weakness in financial market development, as indicated by the domestic credit-to-GDP ratio, highlights an important link between macroeconomic stability and structural policy drivers. Mexico's previous financial crisis contributed significantly to this structural problem as banks spent a long time repairing their balance sheets.

Figure 10. Relative contribution of structural policies to GDP per capita growth 1981-99

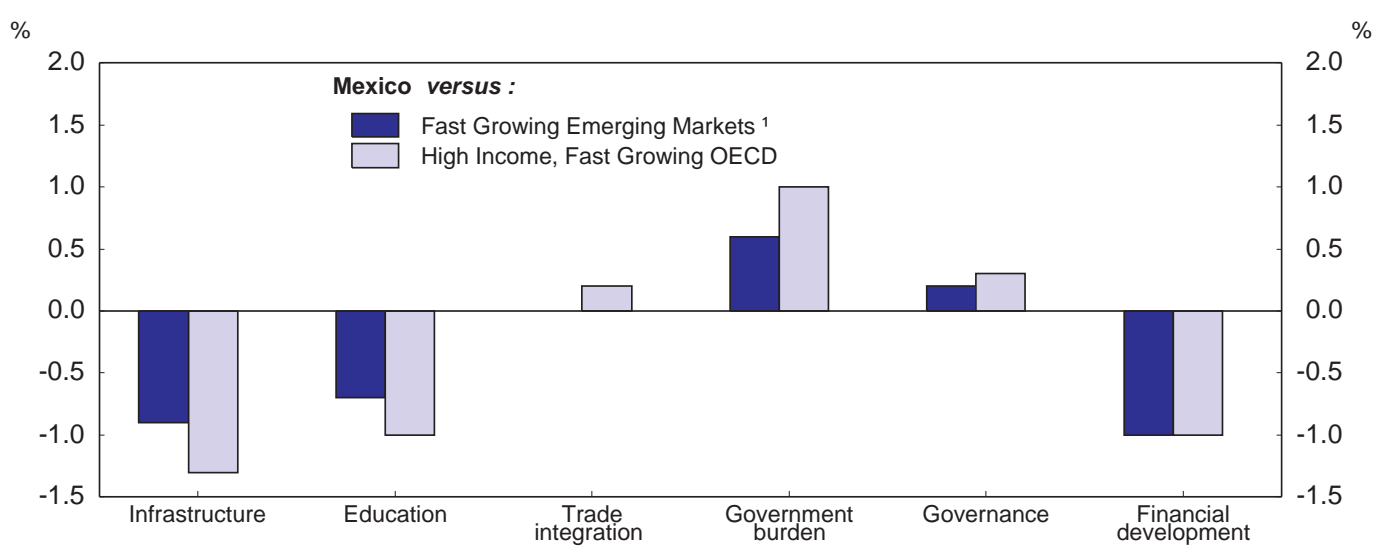

1. Malaysia, Korea and Chile .

Source: OECD simulations using the Loayza, Fajnzylber and Calderón (2005) model. 
21. Estimations based on a cross-country growth model by Sala-i-Martin (1997) between 1960 and 1992 show that initial conditions and, again, weak structural policies largely explain Mexico's weak growth performance. Mexico's low level of human capital, measured by the primary school enrolment rate in 1960, is the largest factor in its underperformance. In addition, four important policy-related variables the years of openness of the economy, the rule of law, the proportion of machinery and equipment in investment and state control of the economy - were also important in explaining Mexico's weaker growth during that period. Although the model is estimated for a period that ended 15 years ago, subsequent developments can be used to determine whether the variables are still relevant and whether the government's current policies are helping to deal with the problems.

22. Estimates with another model by Sala-i-Martin, Doppelhoffer and Miller (2004) also point to the importance of initial conditions in terms of a large convergence gap. The model uses an averaging technique to detect which among numerous potential variables best explains growth. The exercise shows that initial conditions were important in Mexico, especially compared with the faster growing OECD with which Mexico had a large convergence gap. At the same time, this disadvantaged it versus the 10 fastest growing emerging markets, as they were generally poorer than Mexico in 1960. The weak outcome is explained by Mexico's relative poor human capital stock in 1960 vis-à-vis both groups. In addition, human capital measured by life expectancy explains weaker growth vis-à-vis the faster growing OECD countries. Only one policy related variable, openness, measured as the number of years the economy has been open between 1950 and 1994, of the 21 chosen stands out in explaining Mexico's poor performance relative to faster growing countries from 1960-1996. Simulations with the two models above identify convergence as the most important factor that should be contributing to higher growth in Mexico vis-à-vis the OECD countries. This seems obvious given the large income gap.

23. Studies on determinants of growth in Mexico and comparator countries also point to structural weaknesses such as lack of competition as important determinants of weak growth performance. Phillips, Mehrez and Moissinac (2006) compared Mexico with fast-growing countries and found that it has relative weaknesses in physical capital accumulation and in structural factors such as financial development, infrastructure, rule of law (including contract enforcement), education attainments and competition. The findings are in line with other more general growth studies. An extensive panel data regression analysis of growth in the OECD countries also identified the macroeconomic environment, trade openness and financial market development as particularly important for explaining growth differences (Bassanini, Scarpetta, Hemmings, 2001).

24. An important factor explaining slow convergence in Mexico is restrictive product market regulations (PMR) that tend to capture many structural weaknesses. Mexico's PMR level is one of the most restrictive in the OECD (Figure 11). PMRs reduce competition that would motivate firms to enhance productivity by adopting new technologies and processes. Regulation can also have "knock-on" effects on non-regulated sectors of the economy that use the output of the regulated sectors as intermediate inputs. For example, excessive regulation of the electricity sector will have effects on other sectors such as manufacturing where electricity is an important input. Conway, De Rosa et. al. (2006) using a sectoral model of labour productivity growth find that while regulation, measured by the regulatory impact indicators, does not directly lower growth, it impedes convergence towards the global technology frontier. ${ }^{8}$ This is of particular concern for Mexico as it is the convergence process that should be boosting Mexican growth vis-à-vis high income OECD countries.

8. In the model, labour productivity growth is a function of improvements in the global productivity frontier, the gap to the frontier and the speed of convergence, and in some versions, measures of human and physical capital. The model was estimated for 21 OECD countries across 39 industries. 
Figure 11. Product market regulation ${ }^{1}$

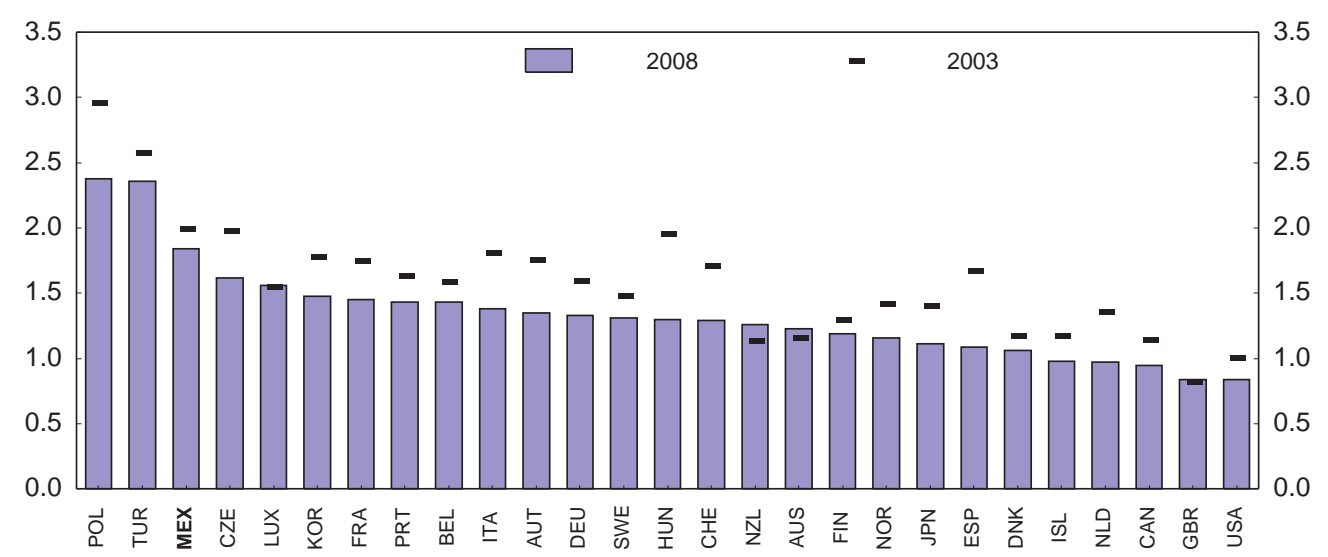

1. Overall indicator, the scale of the indicator is 0-6 from least to most restrictive of competition.

Source: OECD, Product Market Regulation database.

25. To quantify the "knock-on" effects of PMRs across the economy, OECD regulatory impact indicators were calculated for Mexico to compare them with those previously done for 21 other OECD countries (Conway and Nicoletti 2006). ${ }^{9}$, The regulatory impact of PMR in Mexico is above the OECD median for all industries, except in real estate and business services (Figure 12). The largest negative impact is in the network industries (electricity, gas and water) where the regulatory impact of PMR in Mexico is fourfold compared to the OECD median).

9. The indicator measures the regulatory impact on 11 industries in Mexico as the weighted average of anticompetitive PMR in 6 non-manufacturing sectors--electricity, gas and water, post and telecommunications, transport and storage, wholesale and retail trade, other business activities. The weights are proportional to the intermediate input requirements of each of the 11 industries from each of the non-manufacturing sectors. For example, an industry such as paper manufacturing which uses a relatively high amount of electricity as an intermediate input will have a higher weight on PMR in the electricity sector than another industry where less electricity is required per unit of final output. In comparison with the rest of the OECD, the regulatory impact of PMR in the non-manufacturing sectors is relatively high both in the sector and in those such as manufacturing that use their services. More specifically, the weights are the input-output coefficients calculated using the 2003 input-output table (matriz insumo-producto) for Mexico available http://www.inegi.gob.mx. The PMR indicators for the non-manufacturing sectors are obtained from the OECD PMR database available at http://www.oecd.org. In some cases they are simple averages of the indicators for several sub-sectors, for example the transport indicator is the average of the PMR indicators for the airline, road and rail sectors. Figure 5 in Conway and Nicoletti (2006) contains further details. The finance PMR indicator was calculated by de Serres et. al. (2006) and assesses the degree to which regulation encourages or inhibits competition in banking and financial services. For the OECD countries other than Mexico the regulatory impact indicator for total manufacturing is derived by calculating an industry value-added weighted average of the regulatory impact indicator in individual manufacturing industries. 
Figure 12. Knock-on effects of product market regulation at the sector level compared

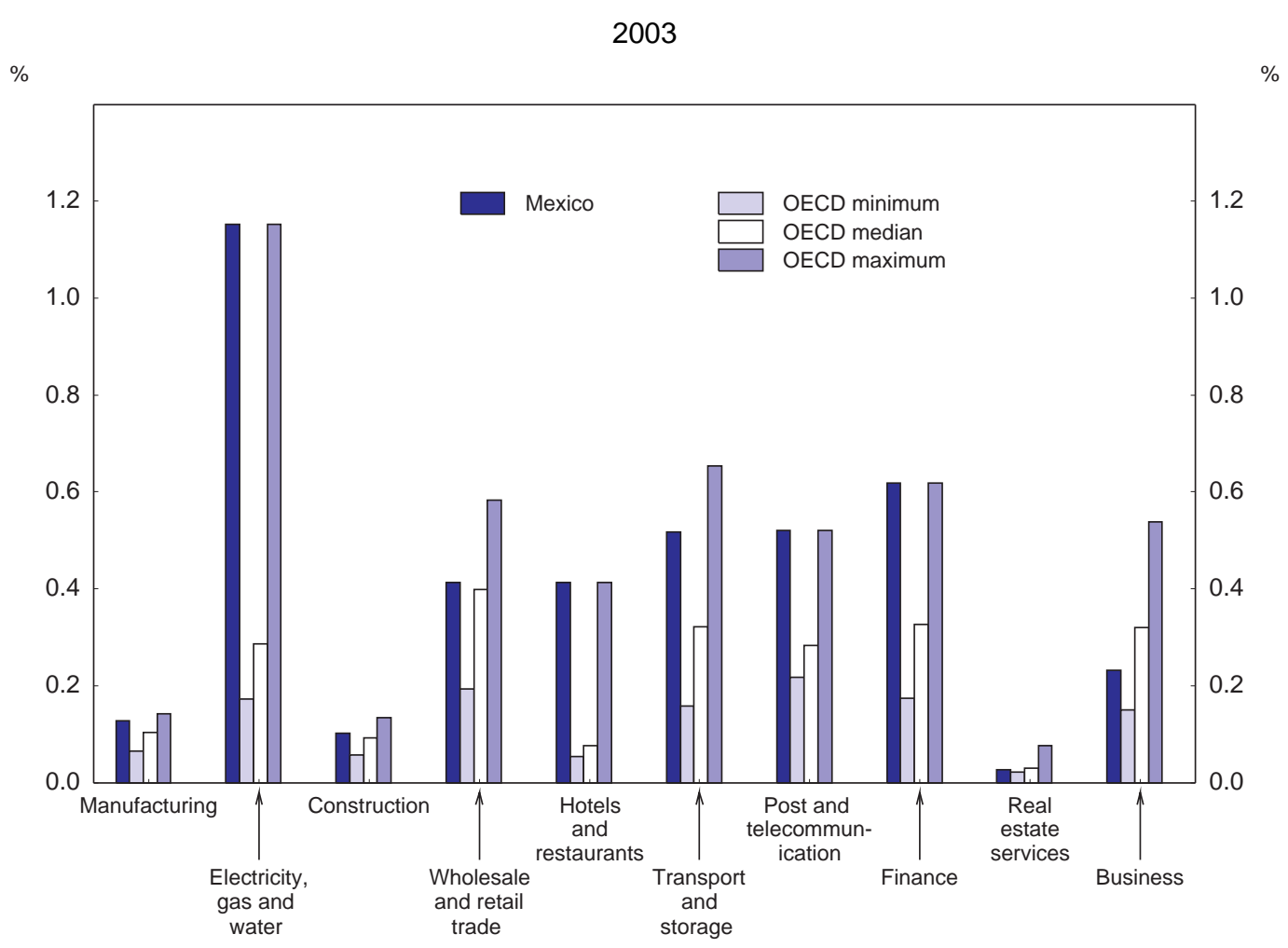

Source: INEGI; OECD, Product Market Regulation database.

26. Frontier model simulations confirm that weak anti-competition regulations have a large negative impact on convergence in Mexico. A simulation by Conway and De Rosa for 21 other OECD countries is repeated to include Mexico. ${ }^{10}$ It is carried out from a steady state in which the level of productivity is the same across all sectors and countries, to which a one-off positive shift in the world productivity frontier of equal size in all sectors is imposed. The shock results in the same productivity gap in all countries and sectors initially but the subsequent speed of convergence towards the frontier depends on the relative restrictiveness of anti-competitive regulations in each industry across countries (Figure 13). Mexico has the slowest convergence in the sample.

10. Coefficients from the sectoral model in Column 2, Table 1B are used in the simulations. Results for countries other than Mexico vary somewhat from the original simulations due to subsequent revisions to the regulatory impact indicators. 
Figure 13. The effect of regulation on the diffusion of a positive supply shock ${ }^{12}$

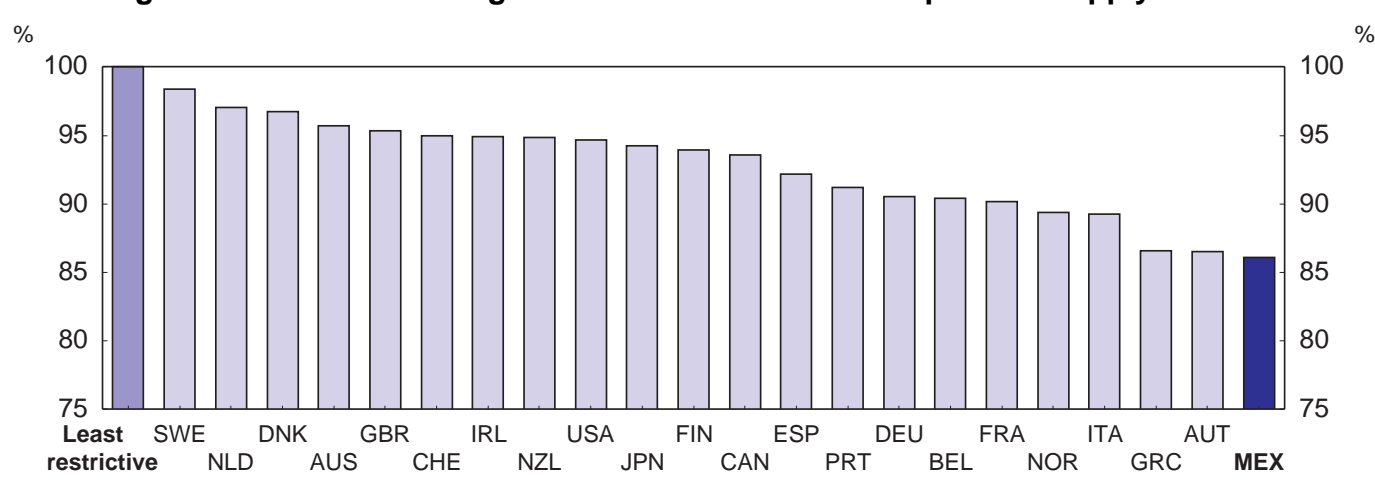

1. The increase in the level of aggregate labour productivity 5 years after a positive supply shock to the world technological frontier of an equal magnitude in each sector. The data are expressed as a percentage of the response that would occur in a country with regulation that is the least restrictive.

2. Productivity is derived as the value-added weighted average of industry-level productivities.

Source: OECD calculations using model estimates from Conway, De Rosa et al.(2006).

27. Another simulation comparing the United States and Mexico also shows that Mexican productivity would be higher with a lower level of PMR. The model compares the actual industry labour productivity gaps between the United States and Mexico in 2005 assuming that US labour productivity remained constant at 2005 levels. It is simulated under two scenarios - Mexico retains the level of PMRs prevailing in 2003, and it moves to the least restrictive PMR existing in the OECD across all industries in 2005. This shows that after 10 years Mexico's labour productivity level would be about $12 \%$ higher if it introduced regulatory reforms. Even after 20 years of catch-up it would still have a labour productivity level 8\% higher than if it retained 2003 PMR levels (Figure 14).

\section{Where to from here? Policy priorities for lifting growth further}

28. To boost Mexico's weak but improving growth performance the above analysis points to both macroeconomic and structural factors. Mexico has improved its macroeconomic stability in recent years, which partly explains the improvements in its growth performance this decade. However, structural reform to boost productivity seems to have been slower and the list of needed reforms is long. The recent significant reductions in import tariffs should help the economy take fuller advantage of trade and investment integration, which could be a relative strength for Mexico given its geographic location. Reforms introduced in the past two years, including those to promote competition and transparency in the financial sector and, to a lesser extent in telecommunications, will also stimulate the dynamism of the economy. Despite this progress, further reforms are needed to boost overall and within-sector productivity. Relative weaknesses in education (Schwellnus 2009), infrastructure, financial development, the rule of law, as well as a lack of competition arising from overly restrictive product market regulation and excessive state control come out in various studies as explaining why Mexico has not grown as fast as other countries. ${ }^{11}$

29. Going forward it is important to identify most relevant growth-boosting reforms while taking into account ongoing efforts. Some of the model estimations reflect time periods when many reforms were not yet in place in Mexico and may thus give a distorted picture of today's priorities. Circumstances and policies change and problems that held growth back in the past are not always relevant for the performance

11. Machinery and equipment investment levels no longer appear to be lower than in faster growing countries. Mexico's proportion of machinery investment as a share of GDP between 1993 and 2007 is considerably higher than the value for the 1960-1992 period and more in line with the faster growing countries. 
of the economy going forward. Furthermore, the areas identified in the above simulations as restricting growth in Mexico are not exhaustive but rather pointing to some clear relative weakness compared to faster-growing countries. There are a number of other policies and factors that are likely to influence growth and will need to be addressed if Mexico is to grow faster. These include, for example, security, inequality (Box 2), restrictive employment regulations and innovation policies. ${ }^{12}$ This section examines developments, both during and subsequent to the model estimation periods, to identify which variables remain relevant for lifting incomes in Mexico. It also identifies current government policies that have improved Mexico's growth and where policy action still needs to be taken.

Figure 14. Simulated convergence of labour productivity towards the United States

Convergence with least restrictive PMR - convergence with Mexico's PMR in 2003

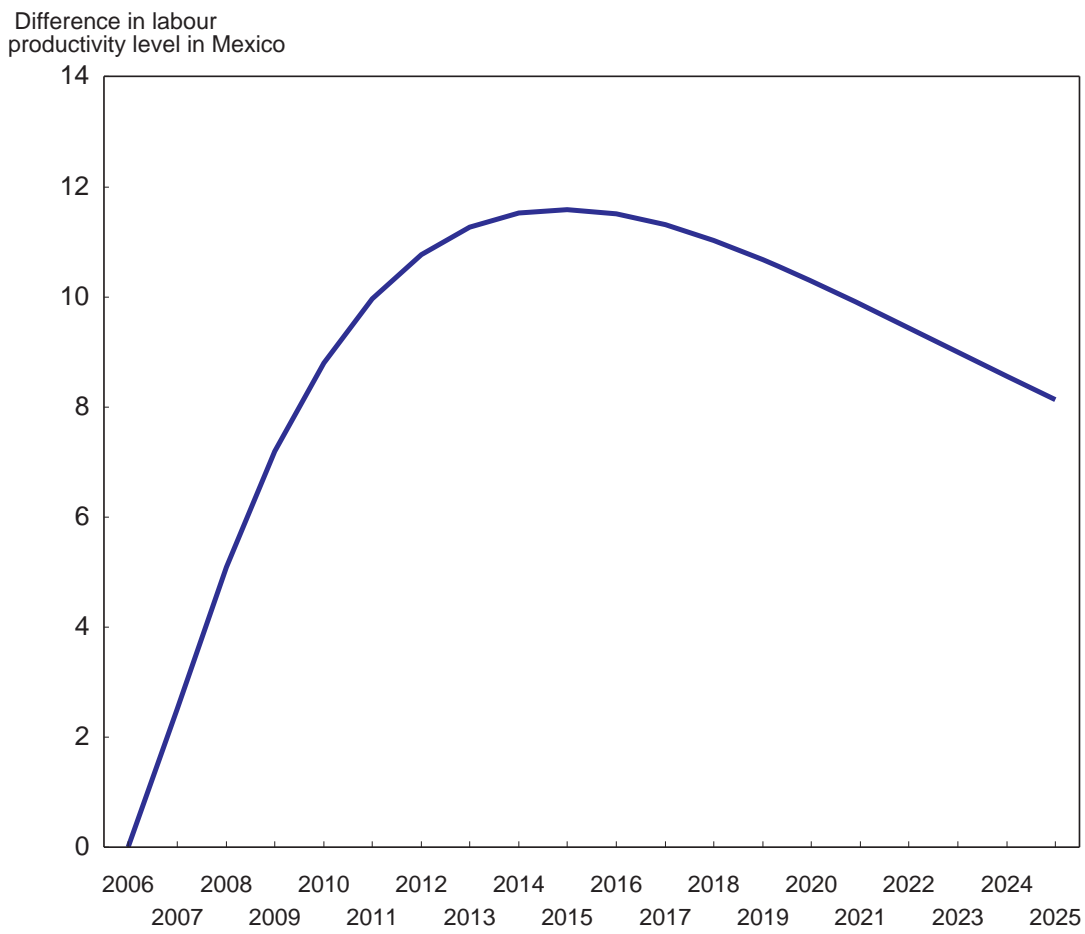

Source: OECD calculations using model estimates from Conway, De Rosa et al. (2006).

12. Innovation policy in Mexico is discussed in OECD (2009b). 


\section{Box 2 Growth and Inequality - lessons for Mexico from the current literature}

Figure 15. Inequality in Mexico : across countries and over time
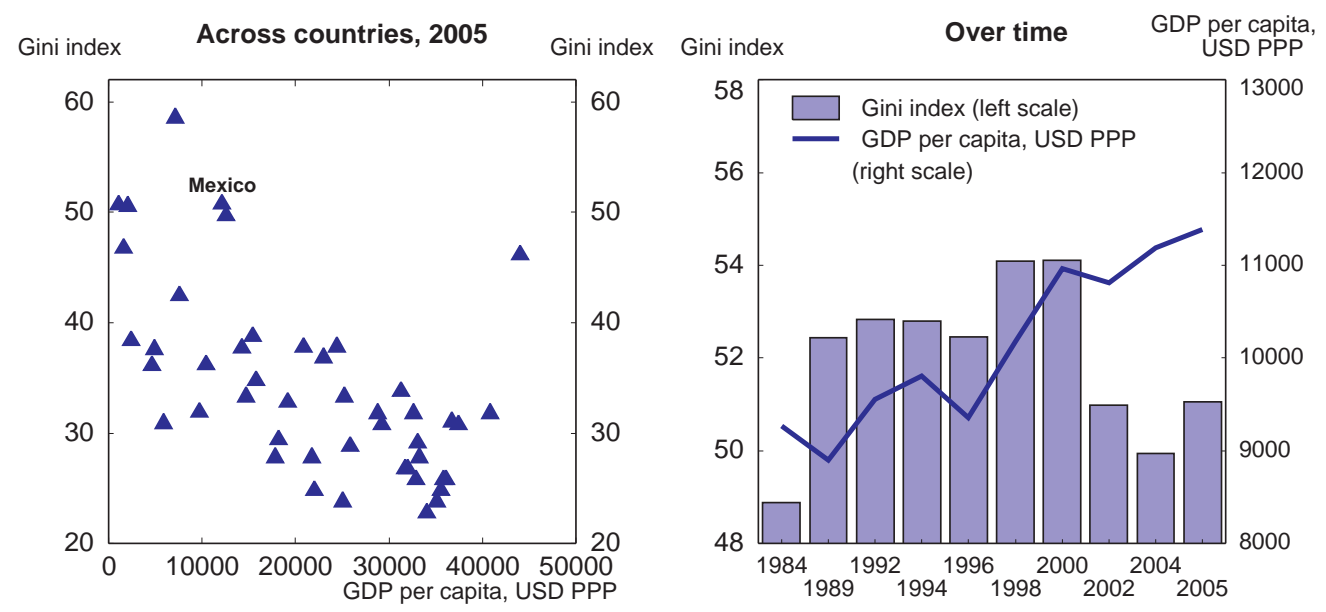

Source: UN WIDER inequality database; World Bank WDI database.

Views have evolved over time on the links between growth and inequality but there seems to be no clear causality from one to the other. Kuznets hypothesized in the 1950's that in the initial phases of development income inequality increases, as an economy moves away from agriculture towards industry. As the economy matures and the industrial sector expands, income inequality decreases. More recent theories suggest that growth driven by skill biased technical change may increase income inequality as wages of lower skilled workers decline in relative terms. However, the consensus view is that there is no robust causal link from growth to inequality (Easterly, 1999, Dollar \& Kraay, 2002).

Another strand of literature has focused on the inequality-to-growth link, but with no conclusive evidence. On the one hand, inequality could promote growth through the accumulation of physical capital as rich individuals have higher savings rates, and capital indivisibilities require large-scale private investments and tend to improve incentive structures. On the other hand, inequality is harmful for growth if it reduces accumulation of human capital in the presence of credit constraints, and increases demand for redistribution through taxation and sociopolitical unrest. However, empirical evidence on these links is inconclusive. Some find that initial inequality has a negative effect on subsequent growth (Alesina \& Rodrik, 1994, Perotti, 1996) in pooled cross-country regressions, but the effect becomes insignificant or positive when unobserved cross-country heterogeneity is taken into account (Barro, 2000 and Forbes, 2000)

Two of the channels highlighted by the literature on the relationship between inequality and growth are of particular relevance for Mexico. The literature on the missing growth-to-inequality link implies that growth in per capita income alone may not be sufficient to reduce inequality in Mexico. While cross-country evidence suggests that reducing income inequality would not be sufficient to boost long-term growth in Mexico, inequality can affect growth in Mexico by reducing human capital accumulation through poor education outcomes (Galor \& Zeira (1993), and by increasing sociopolitical instability (Alesina \& Perotti, 1996). 
Figure 16. Inequality and political stability

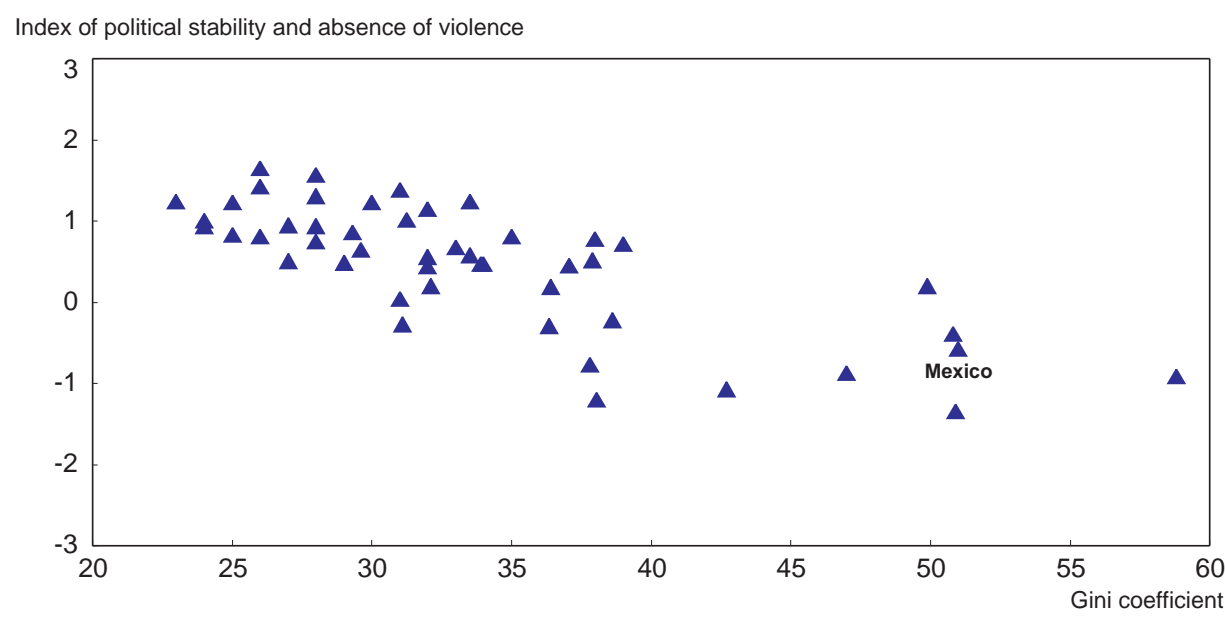

Source: UN WIDER inequality database; World Bank governance indicators.

Therefore, growth in Mexico could benefit from specific measures aimed at reducing inequality. While reducing inequality through direct income transfers may not be possible due to a weak tax base, the government can take other targeted measures. Improving access to secondary education to poor families can ensure that inequality does not prevent low-income individuals from accumulating human capital. This can be done by expanding the Oportunidades programme of cash grants to parents in exchange for school attendance, and facilitating the transition from school to the labour market. These efforts would also help reduce sociopolitical instability and violence in the long run.

\section{Macroeconomic stability}

30. Broadly sound macroeconomic policies are contributing to good growth performance and should continue. Macroeconomic management of the economy has improved substantially since the 1995 Tequila crisis, as evidenced by a drop in inflation, small current account and fiscal deficits, low public and foreign debt, and a comfortable reserve cover. Mexico's commitment to macroeconomic stability, including an independent inflation targeting central bank and fiscal prudence are important cornerstones of this improved performance and should continue.

\section{Openness and trade and investment integration}

31. Lack of trade integration has ceased to be a major hindrance to growth. Trade integration was an issue for growth prior to the early 1990s, but subsequent liberalization episodes (WTO 1986, NAFTA 1994, unilateral actions) have substantially increased the share of trade in GDP - from 39\% in 1990 to $67 \%$ in 2008. Simulations with the Loayza et al. model show that lack of trade integration is no longer a relative weakness vis-à-vis comparators. Furthermore, openness helped Mexico stage a rapid recovery after the 1995 crisis by facilitating strong export growth (Cerra and Saxena, 2005, Tornell, Westermann and Martinez, 2004). ${ }^{13}$

32. Continuing with recent progress on more liberalization could make trade and investment integration more of a strength for growth. The strong export growth in the late 1990s has weakened more recently. Similarly, FDI that has been close to the OECD average in terms of GDP is on a declining trend

13. A full recovery is a return to the projected trend level of GDP existing prior to the crisis. 
and below rates seen in other catching-up countries in the OECD. It is also concentrated in the manufacturing and finance sectors where barriers to investment are lower. At the end of 2008, Mexico's trade policy was more restrictive (on a combined measure of tariff and non-tariff barriers) than the OECD average and other emerging market countries (Haugh, Rocha and Jamin, 2008). The substantial reductions in tariffs announced in December 2008 are a step in the right direction. Investment barriers, including those for FDI, remain higher than in most OECD and Latin American countries (OECD, 2009a). Further opening up of sector to private investment and to FDI would contribute to increase productivity. This would be the case particularly in service and infrastructure sectors, including energy, transport and telecommunications that provide inputs for the whole economy. Further reforms to boost trade and investment integration could reinforce openness as a relative strength for growth in Mexico, improve its ability to take advantage of recovery when it comes, and even help offset other disadvantages that are more difficult to remedy.

33. Given its assets, including geographical position, Mexico's potential gains from further trade and investment liberalisation are high. Equations estimated across a panel of OECD countries indicate that an increase in trade integration of 10 percentage points of GDP (combined measure of export intensity and import penetration) would raise output per working-age person by $4 \%$ (OECD, 2003). OECD estimates also suggest that reducing FDI restrictions to those prevailing in the least restrictive country in the OECD would increase the stock of FDI in Mexico by 50\% (Nicoletti et al., 2003), with consequent benefits for growth through technological transfer, increased competition and innovation.

\section{Financial market development}

34. Boosting Mexico's low financial development should also help growth. Despite progress, Mexico's financial sector remains underdeveloped compared to emerging market peers. Domestic credit to the private sector at about $20 \%$ of GDP is low compared to countries with similar income levels. For example, Chile and China (Figure 16b) were close to $80 \%$. Adding credit directly from abroad increases the ratio only to $25 \%$ of GDP. Similarly, while stock market capitalisation has grown from $32 \%$ of GDP in 1996 to $42 \%$ in 2006 , it still remains well below the OECD average of $121 \%$ and levels in other fast growing emerging markets such as Chile, China, India and Korea (Figure 17c).

35. Building on recent reforms Mexico can further promote financial development (IMF, 2007). Mexico introduced reforms to improve the regulation of the financial sector early in the decade and credit growth accelerated until the recent turmoil especially to households. Given the large gap between financial sector depth in Mexico and faster-growing countries, Mexico should reinforce reforms in this area, including those related to the rule of law (see below). At the same time, it is important that any expansion in financial sector depth is sustainable and that the government maintains fiscal discipline as public-sector debt has crowded out lending to the private sector in the past.

\section{The rule of law and enforcing credit contracts}

36. The rule of law remains the greatest outstanding growth-related problem in Mexico according to the Sala-i-Martin 1997 model. A comparison of Mexico with the average rule of law prevailing with the 10 fastest growing countries in the model shows that Mexico's rule of law has worsened between 1996 and 2007 in absolute and relative terms. The enforceability of contracts, a part of the rule of law that is important for the business environment and the financial sector in particular, is weak. This is evidenced, for example, by much higher debt recovery costs than the OECD average and many other emerging markets, including Argentina, Brazil, Chile and China in 2007 (Figure 18). This may also have contributed to the low level of financial development. Recent government estimates also show that security problems are reducing annual growth by about 1 percentage point. Increasing security in Colombia, for example, has been shown to have substantial growth effects. 


\section{Education and human capital}

37. Improving human capital by further reforms in the education system remains another priority for growth with positive spillovers to sustaining demand during the crisis. The model simulations showed that relative weakness in human capital explains much of the slower growth performance compared to fast-growing countries. Indeed, human capital in the working age population (as measured by average years of schooling) is the lowest in the OECD and other emerging markets despite Mexico spending more than the OECD average on education as a share of GDP. Furthermore, the education system has not generated the large inter-generational increases in educational attainments observed in faster-growing economies such as Greece or Korea (Guichard, 2005, OECD, 2007). Only about two-thirds of the relevant age group attend secondary school.

38. Recent reforms to improve educational quality should be complemented by improving access to education further. Mexico has initiated innovative reforms in education through the Oportunidades programme that aimed at targeted interventions to improve access to schooling of lower income groups. This may have contributed to the increase in secondary enrolment rates between 1996 and 2005 after stagnation between 1981 and 1995. This growth is similar to other fast-growing emerging markets. However, in terms of educational quality, Mexico is lagging both OECD and emerging market countries (as measured by PISA scores). Faster-growing emerging markets such as Chile, China, Poland and Turkey are generating better education outcomes relative to their income level than Mexico (Schwellnus 2009). Raising educational attainment and particularly the quality of educational outcomes in Mexico should remain a policy priority if Mexico is to lift its growth rate further. 


\section{ECO/WKP(2009)74}

Figure 17. Domestic credit to the private sector and stock market capitalisation

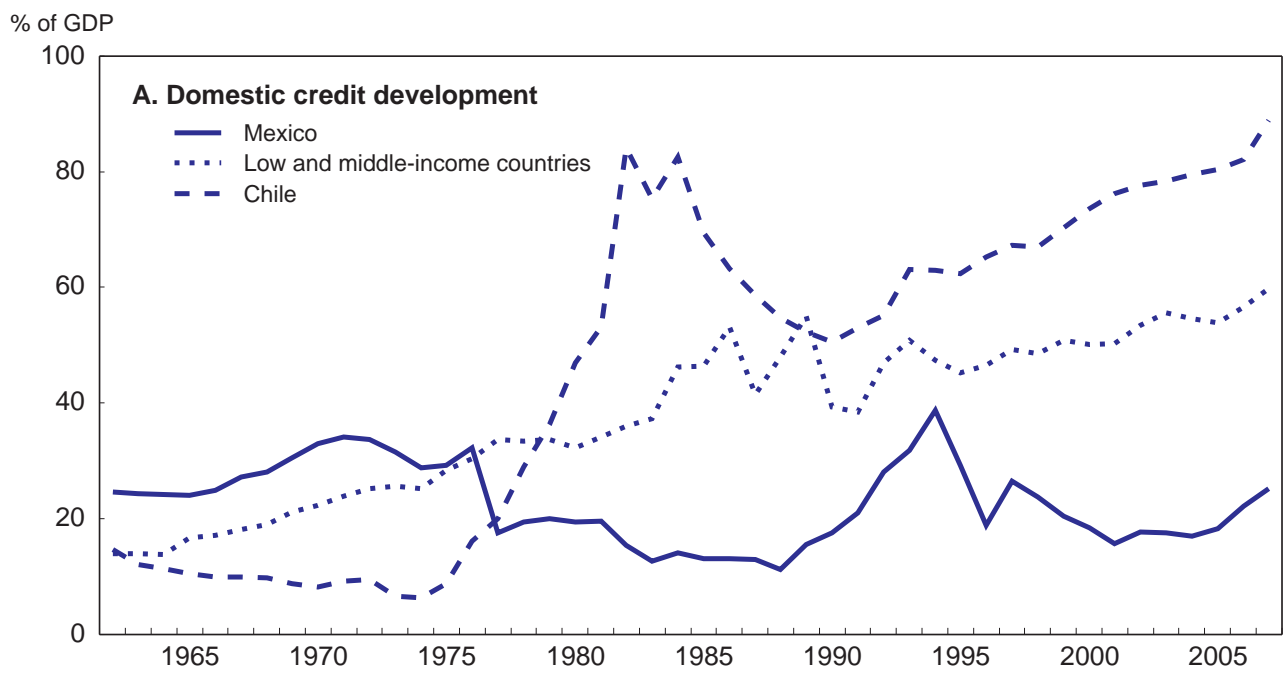

GDP per capita 2006, USD PPP's
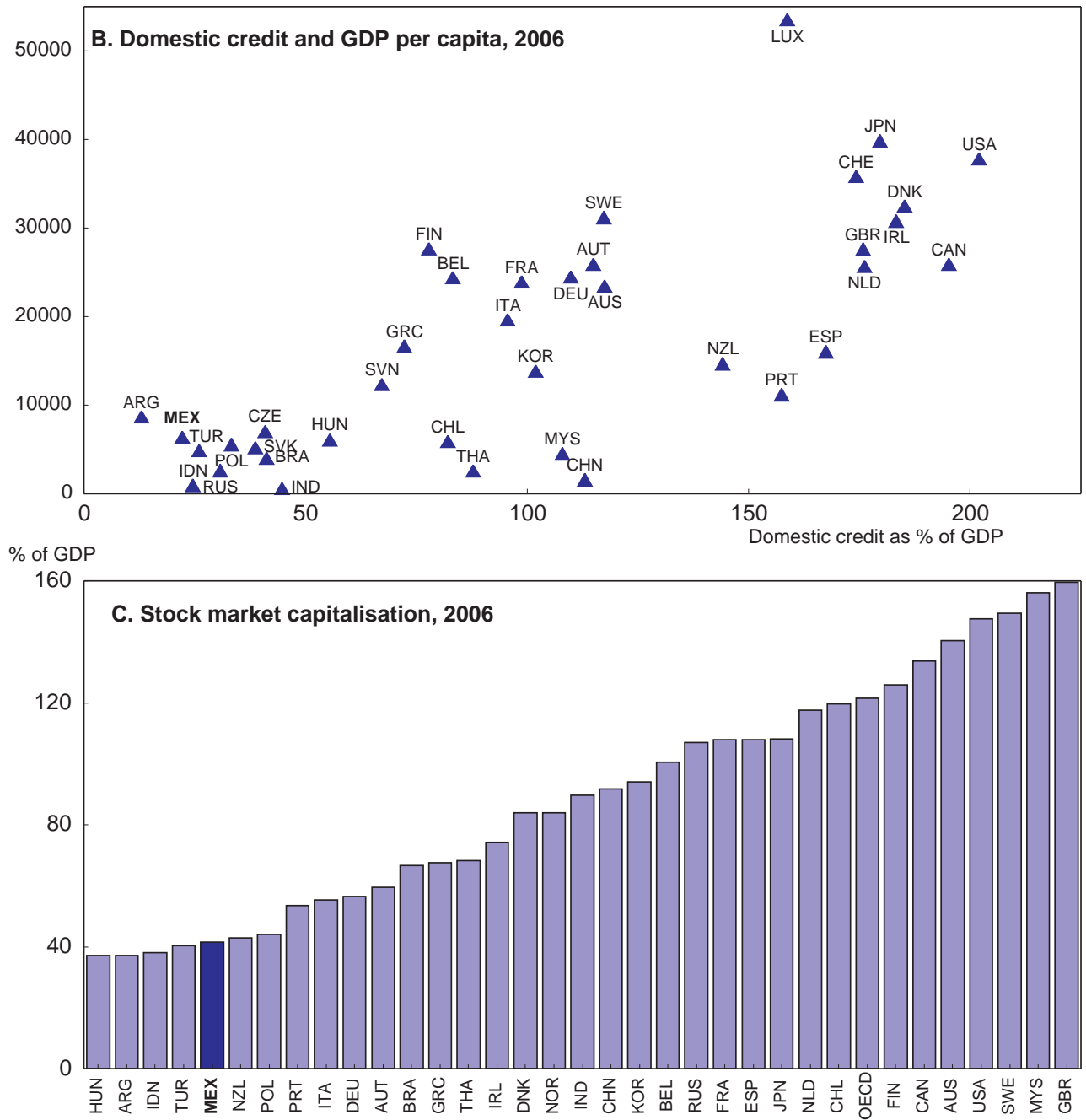

Source: World Bank, World Development Indicators. 
ECO/WKP(2009)74

Figure 18. Cost of enforcing contracts, 2007

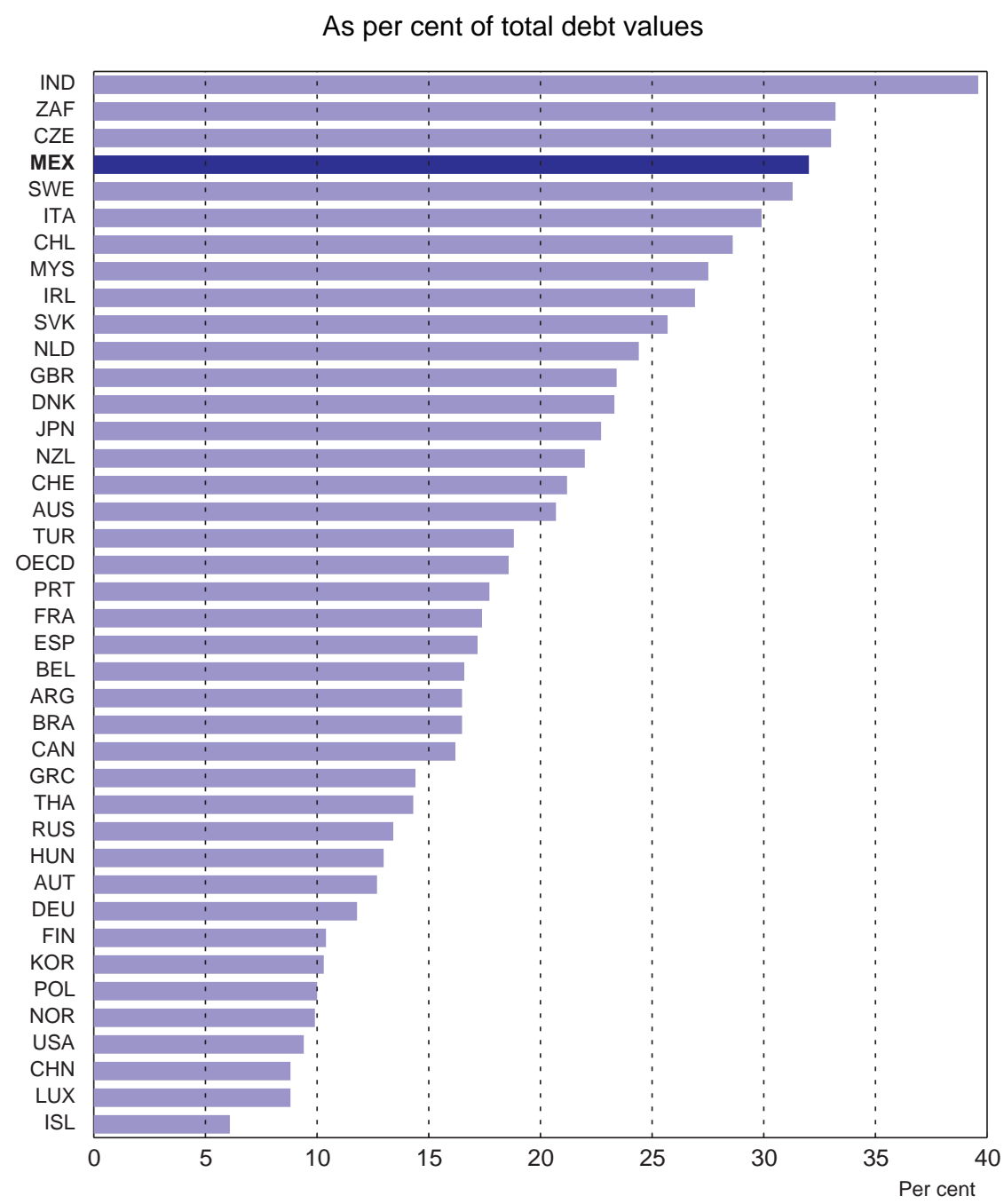

Source: World Bank, World Bank Cost of Doing Business, 2008.

\section{Regulation and competition}

39. Convergence and recovery would also be boosted by increasing competition by reducing product market regulations. Apart from directly restricting competition, the regulatory framework is not facilitating new entrants. For example, it is not providing adequate, non-discriminatory third party access to networks in areas such as telecommunications and railways (OECD, 2007). The result is an economy with high levels of concentration and ineffective competition in many sectors. Coupled with restrictive foreign trade and investment policies this is reducing both the ability and incentive to innovate and adopt new technology and practices from abroad that are important for higher productivity growth and rapid recovery. This applies in particular to telecommunications. Deregulation was among the most important determinants of the growth advantage of the United States and other English-speaking and small EU countries over the past two decades (Nicoletti and Scarpetta, 2005). However, this may not be sufficient to generate competition, especially in network industries such as telecommunications, which underlines the importance of a regulatory regime that facilitates entry and new acquisitions. 
40. Mexico's decision to conduct a project to strengthen competitiveness is an important step to achieve higher levels of investment, employment and growth. This process involves identifying and modifying regulations and policies that unnecessarily restrict competition, and evaluates the regulatory and legal difficulties facing enterprises, using the OECD Competition Assessment Toolkit (Box 3). The large number and complexity of laws and regulations that impede competition mean that an ongoing commitment will be required to gain the maximum return from this strategy. ${ }^{14}$ The experience in Australia, where a similar process was conducted, suggests that such an effort is well justified by the subsequent growth benefits, which are likely to be substantial. Indeed, Australia outperformed the OECD for several years in both GDP and GDP per capita growth terms since the commencement of the regulatory review there in 1993. Its performance is currently less impressive and the government attributes that at least in part to a reduced emphasis on pro-competition reforms lately. Consequently, Australia plans to ratchet up these actions in the years to come.

41. Reforms to boost access to network industries can help sustain the competitive advantage gained from the recent real depreciation and help a rapid recovery when world trade picks up. The productivity gains can be substantial according to the studies reviewed. The government has taken important recent steps to improve competition especially in the telecommunications area by introducing number portability and lowering interconnection charges. In addition, plans to carry out additional auctions of radiospectrum frequencies and of new fiber optic networks should further promote competition in the sector. Additional reforms would complement those envisaged by the Ministry of Economy to create a one-stop-shop for business registrations and aid to start-up companies. By attracting investment to new activities the reform would also help the recovery.

\section{Box 3. Reducing unnecessary restraints on competition using the competition assessment toolkit}

The Mexican government represented by the Ministry of the Economy signed in July 2007 a memorandum of understanding with the OECD to increase Mexico's competitiveness based on two pillars: strengthening competition and improving the regulatory framework. Both pillars developed technical and highly experienced task forces to carry out their process. The competition pillar is coordinated by the Federal Competition Commission (COFECO) and the other group by the Ministry of the Economy. The competition process is conducted using the OECD's Competition Assesment Toolkit (OECD, 2007b). The toolkit contains a checklist that signals when there is a potential competition problem that should be investigated in-more depth (along the lines of those regularly conducted by Competition Authorities). The checklist identifies potential problems if the policy, law or regulation will:

- $\quad$ limit the number or range of suppliers, e.g. establishes a licensing process as an operation requirement; and/or;

- $\quad$ limit the ability of suppliers to compete, e.g. significantly raises production costs of new entrants relative to incumbents; and/or;

- $\quad$ reduce the incentive of suppliers to compete vigorously; reduce mobility of consumers between suppliers.

If a more in-depth investigation reveals that there is an undue restriction on competition, the toolkit contains advice on alternatives that may offset or mitigate potential harm to competition while still achieving the policy objective of the original law/regulation.

Additionally, the project uses the Standard Cost Model to cost administrative burdens, to inform and generate measures of regulatory improvement and administrative simplification.

The review process is being conducted by a group of both economic and legal experts, who provide advice on where problems lie and possibilities for resolving them. The Ministry of the Economy then makes recommendations for regulatory reform to a competitiveness cabinet of ministers. Ensuring the success of this process in eliminating unnecessary restraints on competition and lifting productivity growth will require both ongoing resourcing and ensuring that there is a durable mechanism for implementation.

14. In Australia's case, the National Competition Policy review examined around 1800 laws and regulations over the 1995-2005 period. 


\section{Infrastructure}

42. Increasing infrastructure levels can have positive effects on economic growth and sustaining activity in the downturn. Progress has also been made, with an increase in infrastructure investment from an average of $3 \%$ of GDP in 2000-2006 to 5\% for 2009, but it will take time to close the infrastructure gap, as provision in Mexico is low by OECD standards (OECD, 2008) and Mexico faces a number of challenges in this area. In telecommunications, Mexico tends to underperform other emerging market peers with fewer mainline telephones, fixed, mobile and broadband subscriptions per capita and lower international internet bandwidth per capita (Figure 19). Road and rail provision remains relatively limited, even compared with other emerging markets, as evidenced by the relatively low density of the networks as measured by lines per square kilometre (Figure 20a and b). Despite having lower population densities Argentina, Brazil and Chile have higher road and rail network densities than Mexico. At the same time, existing investments in Mexico seem unbalanced, as many areas are without roads and much is concentrated close to the US border with high user fees. Road congestion, as indicated by the number of vehicles per road kilometre, is also relatively high. In energy, while total electricity generation capacity appears to be adequate or even on the high side in per capita terms at Mexico's income levels, ${ }^{15}$ the reserve margin (total capacity in excess of peak load demand) is high by OECD standards. ${ }^{16}$ Prices also remain relatively high compared with other OECD countries in electricity and telecommunications (OECD, 2007) suggesting that benefits from greater competition such as more innovation and higher productivity are lacking in these sectors. This means that apart from increasing public investment, promoting competition can also help improve both the quantity and quality of infrastructure in Mexico as pointed out by the PMR results discussed earlier.

\section{Figure 19. Fixed and mobile subscribers}

Per 100 people, 2005

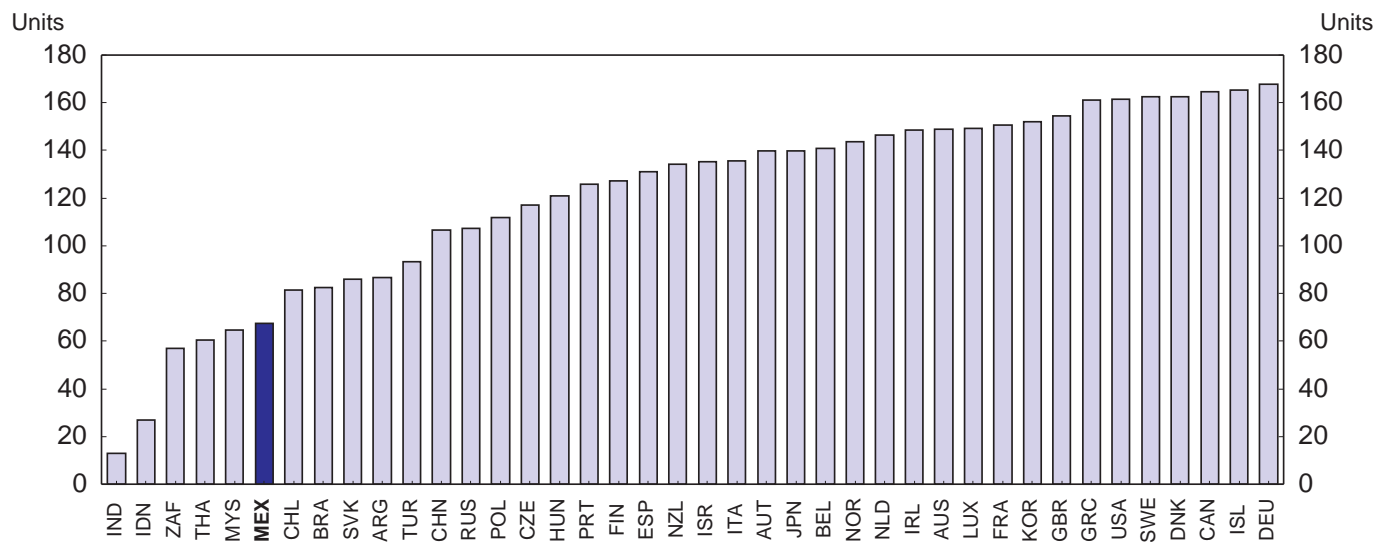

Source: World Bank, World Development Indicators.

15. Generation capacity per capita tends to be higher for richer countries as more economic activity generally requires more electricity use to some degree.

16. See OECD (2008). 
Figure 20. Network density, $2005^{1}$

Kilometres per 1000 square kilometres
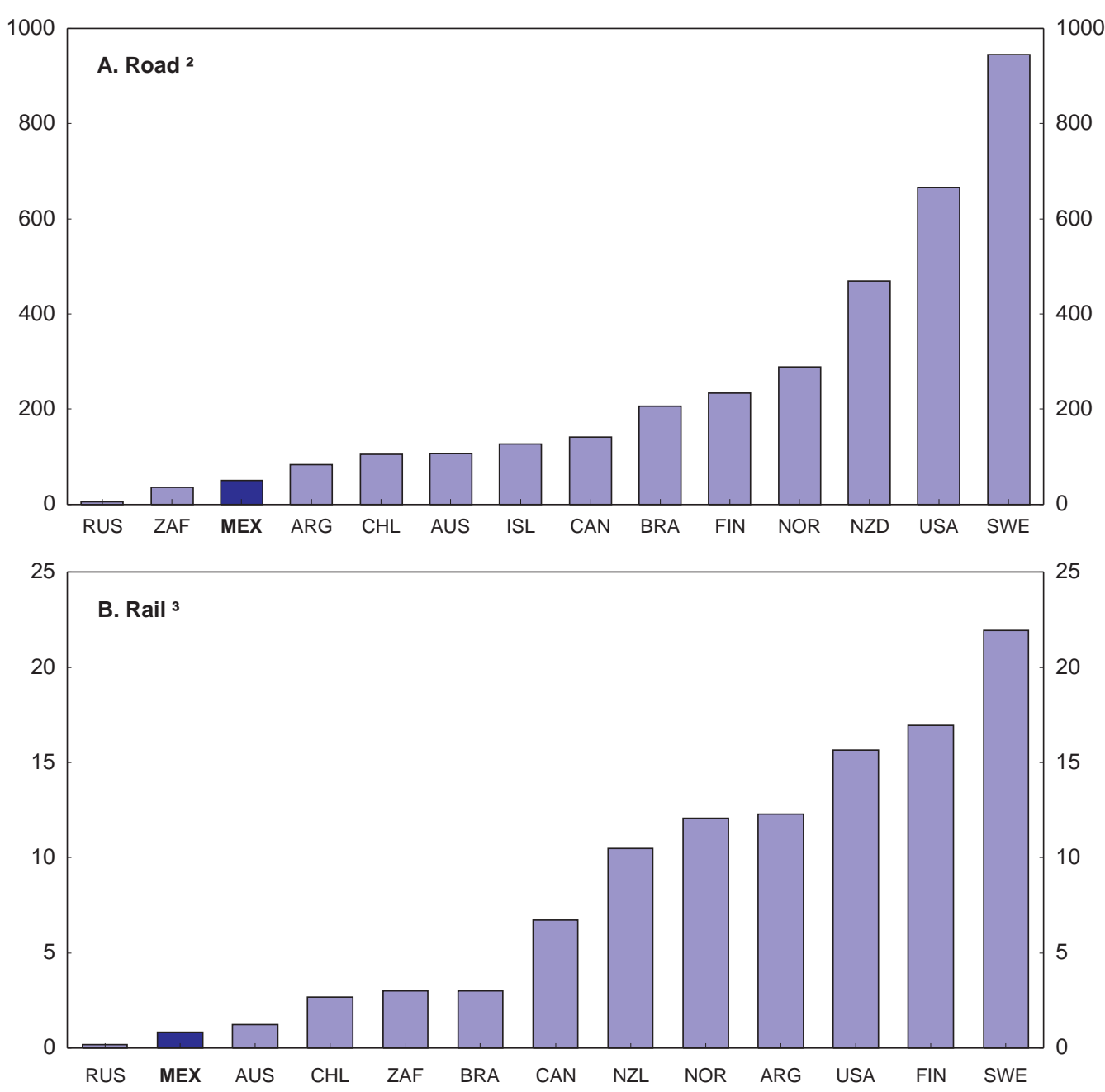

1. Countries with a population density below Mexico's.

2. 2000 for Chile and Russia.

3. 1990 for Argentina and 1998 for New Zealand.

Source: World Bank, World Development Indicators database; North American Transport Statistics.

\section{Concluding remarks}

43. Mexico has made some progress in boosting growth but not enough for satisfactory catch-up. Mexico's reforms, especially those to increase macroeconomic-stability and open the economy to greater trade and investment over the last decade have paid off. They have facilitated strong export-led growth following the 1995 financial crisis and reduced macroeconomic imbalances and vulnerabilities with some positive impact on growth. Mexico now enjoys a level of macroeconomic stability that rivals many higher income countries in the OECD. The economy has become far more integrated in the world economy than two decades ago, increasing the pressure on firms to innovate and exploit the possibilities for technology transfer, especially in the more open manufacturing sector. Taken together, these factors have helped increase GDP per capita growth from near zero in the late 1980s to around 2\% in the 2002-07 period. Although this is around the OECD average, it is too low to allow rapid convergence to living standards in 
the higher-income OECD countries. As an emerging market with a large income gap to the rest of the OECD, and a long border with the world's largest single market, Mexico should be doing much better than the average.

44. However, convergence to higher living standards is far from automatic and requires addressing structural weaknesses more rigorously. A comparison of Mexico's performance with better performing emerging markets and OECD countries reveals that Mexico's weaker growth is largely driven by lower labour productivity growth. To raise labour productivity, more reforms are needed on the structural front. Relative weaknesses in competition, education, the rule of law, infrastructure, and financial development are areas that explain Mexico's poorer performance relative to faster growing countries in the past. There have been important improvements in several of these areas, but efforts along these lines need to continue going forward (see Annex 1.A1, and OECD 2009a). Further opening up the economy to higher private investment, both domestic and foreign, would also contribute to higher productivity.

45. Although reforms are needed on a broad front, rapid progress with limited resources can be obtained by focusing reforms on increasing competition. Mexico also needs to monitor and ensure previous reforms in areas such as financial markets deliver their aims. It should also complement this with further policy change to deal with persisting structural weakness. Recent OECD work contains detailed recommendations for improving education outcomes, lifting competition and improving infrastructure, increasing the benefits from international trade and investment, especially in the telecommunication sector.

\section{Box 4 Policy recommendations for boosting growth and spurring economic recovery}

Boost competition to enhance productivity, growth and recovery

- Increase competition in the main network industries--electricity, gas, water, telecommunications and transport-- through regulatory action.

- $\quad$ Further liberalise investment regimes by reducing both barriers to domestic and foreign investment. Enhance trade links with Asia to diversify trade.

- Increasing competition and reducing entry barriers in telecommunications further is of particular importance for the diffusion of new technologies.

Sustain demand and improve competitiveness with a better infrastructure

- $\quad$ Focus on sectors with rapid pay-offs such as education (coverage and quality, see Chapter 3 ), and transport networks (road, rail and ports).

- $\quad$ Continue to increase infrastructure spending provided capacity constraints allow it. 


\section{Bibliography}

Adrogué, R. M. Cerisola and G. Gelos (2006), "Brazil's Long-Term Growth Performance- Trying to Explain the Puzzle", IMF Working Paper, No. 06/282.

Alesina, A. and D. Rodrik, (1994), "Distributive Politics and Economic Growth", The Quarterly Journal of Economics . 109, No. 2 (May, 1994).

Barro, R. J. (2000), "Inequality and Growth in a Panel of Countries", Journal of Economic Growth, March 2000.

Bassanini, A., S. Scarpetta and P. Hemmings (2001), "Economic Growth: The Role of Policies and Institutions. Panel Data Evidence from OECD countries", OECD Economics Department Working Paper, No. 283.

Cerra, V. and S.C. Saxena (2005), "Growth Dynamics: The Myth of Economic Recovery", IMF Working Paper, No. 05/147.

Conway, P., D. De Rosa, F. Steiner and G. Nicoletti (2006), "Regulation, Competition, and Productivity Convergence", OECD Economics Department Working Paper, No. 509.

Conway, P. and G. Nicoletti (2006), "Product Market Regulation in the Non-Manufacturing Sectors of OECD Countries: Measurement and Highlights", OECD Economics Department Working Papers, No. 530.

De Serres, A., S. Kobayakawa, T. Sløk and L. Vartia (2006), "Regulation of financial systems and economic growth", OECD Economics Department Working Papers, No. 506.

Dollar, D. \& A. Kraay, (2002), "Growth is good for the Poor", Journal of Economic Growth, Vol. 7.

Easterly, W. (1999), "Life during Growth”, Journal of Economic Growth, Vol. 4, No. 3.

Forbes, K. J. (2000), "A reassessment of the Relationship between Inequality and Growth", The American Economic Review, Vol. 90, No. 4.

Galor, O. \& J Zeira, (1993), "Income Distribution and Macroeconomics", The Review of Economic Studies, Vol. 60, No. 1.

Guichard, S. (2005), "The Education Challenge in Mexico: Delivering Good Quality Education to All", OECD Economics Department Working Papers, No. 477.

Haugh, D., B. Rocha and R. Jamin (2008), "Maximising Mexico's gains from integration in the world economy", OECD Economics Department Working Papers, No. 657.

IMF (2007), "Mexico: Financial Sector Assessment Program Update - Technical Note - Financing of the Private Sector", IMF Country Report No. 07/170. 
Lenain, P. and L. Rawdanowicz (2004), "Enhancing Income Convergence in Central Europe after EU Accession," OECD Economics Department Working Papers, No. 392.

Loayza, N., P. Fajnzylber and C. Calderón (2005), Economic Growth in Latin America and the Caribbean: Stylized Facts, Explanations and Forecasts, World Bank, Washington D.C.

Lucas, R. (1988), "On the Mechanics of Economic Development", Journal of Monetary Economics.

Phillips, S., G. Mehrez and V. Moissinac (2006), "A Survey of Conditions for Growth in Mexico:, in International Perspective", in IMF Country Report No. 06/351.

Maddison, A. (2003), "The World Economy: Historical Statistics", OECD Development Centre Studies.

Nicoletti, G.S., S. Golub, D. Hajkova, D. Mirza and K.Y. Yoo (2003), "Policies and International Integration: Influences on Trade and Foreign Direct Investment", OECD Economics Department Working Papers, No. 359.

Nicoletti, G.S., and S. Scarpetta, (2005), "Regulation and Economic Performance: Product Market Reforms and Productivity in the OECD”, OECD Economics Department Working Papers, No. 460.

OECD (2003), The Sources of Economic Growth, Paris, OECD.

OECD (2007) OECD Economic Survey of Mexico, Paris, OECD.

OECD (2007a) Pisa 2006: Science Competencies for Tomorrow's World, Vol. 1, Paris, OECD.

OECD (2007b) OECD Competition Assessment Toolkit, Version 1.0, Paris, OECD.

OECD (2008) "Infrastructure Investment: Links to Growth and the Role of Public Policies", OECD Economics Department Working Paper, forthcoming.

OECD (2009a) Going for Growth, Paris, OECD.

OECD (2009b) Review of Mexico's Innovation Policies, Paris (forthcoming)

Perotti, R. (1996), "Redistribution and Non-consumption Smoothing in an Open Economy", The Review of Economic Studies, Vol. 63, No. 3.

Romer, P. (1990), “Endogenous technological change”, Journal of Political Economy.

Sala-I-Martin, X. (1997), "I Just Ran Two Million Regressions", The American Economic Review, Vol. 87, No. 2, pp. 178-183.

Sala-I-Martin, X., G. Doppelhoffer and R. Miller (2004), "Determinants of Long-Term Growth: A Bayesian Averaging of Classical Estimates (BACE) Approach. The American Economic Review, Vol. 94. No. 4, pp 813-835.

Scarpetta, S., A. Bassanini, D. Pilat and P. Schreyer (2000), "Economic growth in the OECD area: Recent trends at the aggregate and sectoral level", OECD Economics Department Working Paper, No. 248.

Schwellnus, C., (2009), "Achieving higher performance: Enhancing spending efficiency in health and education in Mexico", OECD Economics Department Working Paper, No. 732. 
Solow, R. (1956),"A Contribution to the Theory of Economic Growth", The Quarterly Journal of Economics, 70, pp 65-94.

Solow, R. (1957), "Technical Change and the Aggregate Production Function", The Review of Economics and Statistics, Vol. 39, pp 312-320.

Solow, R. (1961), "Note on Uzawa's two sector model of economic growth", Review of Economic Studies.

Swan, T. (1956), “Economic Growth and Capital Accumulation”, Economic Record, Vol. 32, pp 334-361.

Timmer, M.P. and G. J. de Vries (2007), "A Cross-Country Database For Sectoral Employment And Productivity In Asia And Latin America, 1950-2005", Groningen Growth and Development Centre Research Memorandum GD-98.

Timmer, M.P., M. O'Mahony and B. van Ark, "The EU KLEMS Growth and Productivity Accounts: An Overview", University of Groningen \& University of Birmingham available at http://www.euklems.net/.

Tornell, A., F.Westermann and L.Matinez (2004), "Mexico and NAFTA's less than stellar performance", NBER Working Paper, No. 10289.

Uzawa, Hirofumi, .(1961) "Neutral Inventions and the Stability of Growth Equilibrium",

Review of Economic Studies, February 1961, 28 (2), 
ECO/WKP(2009)74

\section{Annex 1.A1}

\section{Progress in structural reform}

1. This annex summarises recommendations made in previous Surveys and action taken since the last Survey was finalised in July 2007. More detailed recommendations based on analysis in this survey are listed in the relevant chapters.

\begin{tabular}{|c|c|}
\hline Recommendations & $\begin{array}{l}\text { Action taken since the previous Survey } \\
\text { (July 2007) }\end{array}$ \\
\hline \multicolumn{2}{|c|}{ A. STRENGTHENING PUBLIC FINANCES } \\
\hline $\begin{array}{l}\text { Strengthen the fiscal framework, ensuring fiscal rules and } \\
\text { guidelines are implemented. Save or invest extra windfall } \\
\text { from non-renewable resources. }\end{array}$ & $\begin{array}{l}\text { Upper bound on the maximum level of stabilisation funds } \\
\text { increased for } 2009 \text {. }\end{array}$ \\
\hline Enhance the efficiency of public spending: & $\begin{array}{l}\text { Performance budgeting reform measures were included in } \\
\text { the } 2007 \text { fiscal reform. Its implementation is in progress. }\end{array}$ \\
\hline Increase tax revenues while reducing distortions & $\begin{array}{l}\text { The } 2007 \text { tax reform (IETU) is aimed at broadening the tax- } \\
\text { base while improving spending efficiency. However, more } \\
\text { reforms on non-oil taxes are needed to reduce dependency } \\
\text { on oil revenues in the budget. }\end{array}$ \\
\hline $\begin{array}{l}\text { Review powers and responsibilities of sub-national } \\
\text { governments }\end{array}$ & $\begin{array}{l}\text { The } 2007 \text { fiscal reform gave them the capacity to raise a tax } \\
\text { on gasoline. }\end{array}$ \\
\hline $\begin{array}{l}\text { Limit growth of federal transfers, to give sub national } \\
\text { government incentives to increase and execute their taxing } \\
\text { power. }\end{array}$ & $\begin{array}{l}\text { Formulas for the transfer of resources to subnational } \\
\text { governments were modified to provide them with higher } \\
\text { incentives to increase their own revenues. }\end{array}$ \\
\hline $\begin{array}{l}\text { Extend the ISSSTE pension reform to other sub-systems for } \\
\text { public sector employees. }\end{array}$ & $\begin{array}{l}\text { The pension systems of CFE and workers of IMSS were } \\
\text { reformed in } 2008\end{array}$ \\
\hline $\begin{array}{l}\text { Reform PEMEX-management, improving governance and } \\
\text { consider allowing of joint ventures, to ensure much needed } \\
\text { capital and technology. }\end{array}$ & $\begin{array}{l}\text { PEMEX reform passed in October } 2008 \text { is being gradually } \\
\text { implemented, mainly improving corporate governance. } \\
\text { Performance based contracts need to be carefully designed } \\
\text { in order to guarantee that they promote higher investment in } \\
\text { the sector. }\end{array}$ \\
\hline \multicolumn{2}{|c|}{ B. TRADE AND FOREIGN INVESTMENT } \\
\hline Gradually reduce applied most favoured nation tariffs. & Substantial rate reduction in effect from January $1^{\text {st }} 2009$. \\
\hline $\begin{array}{l}\text { Reduce non-tariff barriers including: streamlining customs } \\
\text { and technical and labelling standards; eliminating exclusive } \\
\text { entry ports, reference prices and special registration lists for } \\
\text { imported goods. }\end{array}$ & $\begin{array}{l}\text { At the same time the rates were reduced, a wide range of } \\
\text { measures to improve foreign trade procedures were } \\
\text { established. }\end{array}$ \\
\hline Reduce foreign ownership restrictions. & $\begin{array}{l}\text { A new law reducing ownership restrictions in } \\
\text { telecommunications was approved in the lower chamber of } \\
\text { Congress. Approval in the Upper Chamber is pending. }\end{array}$ \\
\hline Further facilitate FDI and maximise benefits from FDI. & $\begin{array}{l}\text { A new law reducing ownership restrictions in } \\
\text { telecommunications was approved in the lower chamber of } \\
\text { Congress. Approval in the upper chamber is pending }\end{array}$ \\
\hline $\begin{array}{l}\text { Strengthen the rule of law to improve business } \\
\text { environment. }\end{array}$ & \\
\hline
\end{tabular}




\begin{tabular}{l} 
Recommendations \\
\hline C. CoMPETITION, REGULATIO \\
Undertake broad review across the economy of legal \\
restraints at both the federal and the state levels on \\
competition. \\
Assign adequate resources to the Federal Competition \\
Commission and other regulators. \\
Improve enforcement of competition law. \\
A. Energy. \\
Electricity: Increase competition in electricity generation, \\
encourage private sector investment. \\
Gas: Continue liberalisation and opening of the sector. \\
B. Telecommunications \\
Facilitate new entry and improve the regulatory framework \\
to enhance competition. \\
Promote broadband including unbundling the local loop. \\
Establish a clear legal framework for setting asset prices. \\
approval.
\end{tabular}

\section{Transport}

Border and trucking: improve efficiency at the US border.
Undertake broad review across the economy of legal
restraints at both the federal and the state levels on competition.

\section{Action taken since the previous Survey}

(July 2007)
The Government with the support of the OECD has launched a broad review of laws and regulations to identify and eliminate unnecessary restraints on competition. The competition commission has increased its capacity for economic analysis in competition areas.

No action.

No action.

No action.

Reform passed aimed at allowing competition in consumer provision.

Authorities have initiated phone number portability Interconnection charges for mobile phone companies to fixed line companies for network traffic reduced by more than 50 percent. Permits to commercialise or resell mobile phone services granted. Additional spectrum and fibre optic network auctions have been announced.

Spectrum Auction program issued in March of 2008. The Basic Technical Plan for interconnection and interoperability issued, enabling i.e. that end user has access to any contents, services or application provided by any operator.

Pilot project with US on cross border trucking. Currently stopped by the new US administration. Authorities are working with US Government to reactivate project within the NAFTA framework.

Privatisation completed fall of 2007 and industry opened to low-cost carriers.

Airlines: proceed with privatisation of Aeromexico as separate entities. Increase foreign owners More use of PPPs introduced. During 2009 SCT will have 38 PPPs underway.

Roads: encourage private sector investment.

No new action.

Railways: introduce an independent regulator and new access pricing rules to resolve interconnection disputes.

Ports: improve port efficiency including improving wharf to land transfer and customs procedures.

Development of logisitics activity zones (LAZ) promoted. A review of operational processes of transfer and manoeuvring of delivery-reception initiated. This has reduced the time goods spend in ports.

\section{PROMOTE A BUSINESS FRIENDLY ENVIRONMENT}

Facilitate entry and exit of firms.

Further progress in implementing the SARE (Rapid Business Start-up System). State and municipal procedures for opening a new low risk business are reduced to up to 3 days.

Reduce business costs. One-stop-shop project initiated.

\section{E. ENHANCING HUMAN CAPITAL}

\section{A. Increase coverage of post compulsory education}

Facilitate access of poorer students to upper secondary Two new scholarship programmes initiated: "National education.

Retention Scholarship Programme" and "Student Support Scholarship Programme".

\section{B. Increase quality of education services}

Modernise curricula and better integrate it between levels.

Evaluate schools and publish results

No action.

Results from the ENLACE evaluation are now published at the school level. 


\begin{tabular}{|c|c|}
\hline Recommendations & $\begin{array}{l}\text { Action taken since the previous Survey } \\
\text { (July 2007) }\end{array}$ \\
\hline Review incentives for teachers & $\begin{array}{l}\text { Alianza reform plans to link teacher incentives to } \\
\text { professional development and student test scores; Carrera } \\
\text { Magisterial is being reformed. }\end{array}$ \\
\hline \multicolumn{2}{|l|}{ C. Facilitate the transition from school to job } \\
\hline $\begin{array}{l}\text { Consider the introduction of apprenticeships contracts for } \\
\text { alternation programmes. }\end{array}$ & No action. \\
\hline Further strengthen vocational education. & $\begin{array}{l}\text { Technical committees have been established to strengthen } \\
\text { school-business links. }\end{array}$ \\
\hline \multicolumn{2}{|l|}{ D. Adult training } \\
\hline Continue implementation of skill certification. & $\begin{array}{l}\text { Enrolment within the skill certification model has increased } \\
45 \% \text { during the } 2007-2008 \text { school year. }\end{array}$ \\
\hline Strengthen public training programmes. & $\begin{array}{l}\text { Work training programmes have been offered within the skill } \\
\text { certification model during the } 2007-2008 \text { school year. }\end{array}$ \\
\hline $\begin{array}{l}\text { Upgrade entrepreneurial competences in small and } \\
\text { medium-size enterprises. }\end{array}$ & $\begin{array}{l}\text { Development banks (Nacional Financiera) have stepped up } \\
\text { their programs to support SMEs, both in terms of additional } \\
\text { financing as well as technical assistance. }\end{array}$ \\
\hline \multicolumn{2}{|c|}{ F. LABOUR MARKETS AND POVERTY ALLEVIATION } \\
\hline \multicolumn{2}{|l|}{ A. Labour market } \\
\hline $\begin{array}{l}\text { Increase the flexibility of employment regulations by easing } \\
\text { employment protection provisions while putting in place a } \\
\text { minimum revenue support in case of job loss. }\end{array}$ & $\begin{array}{l}\text { A reform to the retirement savings system has been } \\
\text { approved to allow workers to have greater access to the } \\
\text { resources in their retirement accounts in case of } \\
\text { unemployment. To make up for this, the Government's } \\
\text { contribution was increased. }\end{array}$ \\
\hline $\begin{array}{l}\text { Introduce probation period, to facilitate job creation through } \\
\text { long-term contracts. }\end{array}$ & No action. \\
\hline Broaden scope for using short term contracts & No action. \\
\hline Broaden scope for using part-time contracts. & No action. \\
\hline \multicolumn{2}{|l|}{ B. Review tax and benefits } \\
\hline $\begin{array}{l}\text { Rebalance incentives towards formal employment by } \\
\text { reviewing the tax-benefit package to improve the reliability } \\
\text { and efficiency of social security services. Increase } \\
\text { attractiveness of individual pension savings (SAR). }\end{array}$ & $\begin{array}{l}\text { Social security law reformed in favour of temporary workers } \\
\text { in the agricultural sector, to ensure their incorporation into } \\
\text { IMMS and earning of pension benefits. }\end{array}$ \\
\hline $\begin{array}{l}\text { Bring in line the public sector pension schemes with the } \\
\text { private sector. }\end{array}$ & $\begin{array}{l}\text { Public sector pensions for new employees have been } \\
\text { aligned with the private sector. }\end{array}$ \\
\hline Avoid use of payroll tax. & No new action. \\
\hline \multicolumn{2}{|l|}{ C. Poverty alleviation and public security } \\
\hline $\begin{array}{l}\text { Adjust coverage of Oportunidades to include all segments } \\
\text { of the poor population. Improve the quality of supply of } \\
\text { health and education within program to increase } \\
\text { effectiveness. }\end{array}$ & No action. \\
\hline $\begin{array}{l}\text { To aid the poor, replace subsidies by targeted cash } \\
\text { transfers. Review effectiveness of programmes like } \\
\text { DICONSA and LICONSA, if inefficient, refocus them or } \\
\text { discontinue them. In general, rationalise the numerous } \\
\text { programs with social objectives to avoid duplication and } \\
\text { draw on synergies. }\end{array}$ & No action. \\
\hline $\begin{array}{l}\text { Review mix of interventions targeted at rural poverty; } \\
\text { reinforce partnerships among actors involved in rural } \\
\text { development. }\end{array}$ & No action. \\
\hline $\begin{array}{l}\text { Increase cost efficiency of IMSS health care to provide } \\
\text { higher quality services at lower costs. }\end{array}$ & No action. \\
\hline $\begin{array}{l}\text { Take steps to integrate health insurance systems and split } \\
\text { financing from providers }\end{array}$ & No action. \\
\hline
\end{tabular}


Annex 1.A2

\section{Data and methodology}

1. The data used in the growth accounting and growth comparisons for emerging markets were sourced from the OECD, the International Monetary Fund (IMF), the World Bank (WB) and the United Nations (UN). Where official data were unavailable, they were supplemented by OECD country desk estimates. Databases included: the IMF's World Economic Outlook (WEO) and the World Development Indicators (WDI) from the WB and the United Nations Statistic Division (UNSD) Database from the UN.

\begin{tabular}{|c|c|c|c|}
\cline { 3 - 4 } \multicolumn{1}{c|}{} & \multicolumn{2}{c|}{ Source } \\
\cline { 2 - 4 } \multicolumn{1}{c|}{} & Definition & OECD members & Non members \\
\hline \multirow{2}{*}{ GDP extension } & GDP in PPP (constant 2005 \$) & OECD & World Bank (WD1) \\
\cline { 3 - 4 } Employment & & OECD & WEO \\
\cline { 3 - 4 } $\begin{array}{c}\text { Working age } \\
\text { Population }\end{array}$ & Segment of the population between ages 15 and 64 & OECD & WEO \\
\cline { 3 - 4 } & & Onalytical Database & United Nations \\
(OECD) & OECD & UNSD \\
\hline Population & & OECD & UNSD \\
\hline
\end{tabular}

Note: In some cases, there is available OECD data for non member countries. In these cases the OECD desk estimations are used instead of the alternative source used for the rest of the non member countries. Series were extended from 1980 to 2012 ; when the whole series was not available from the same source, they were extended extrapolating the growth rates from an alternative database.

2. As the goal of the work is to analyse the long-term growth of the selected countries, cyclical effects were removed by filtering all the time series using a Hodrick-Prescott Filter (HP) with lambda $=100$. The HP filter becomes inaccurate at the end of a time series (Scarpetta, Bassanini, Pilat and Schreyer (2000)). To mitigate this problem, the series were extended before filtering using either OECD forecasts or extrapolation using past average growth rates. 
ECO/WKP(2009)74

Annex 1.A3

\section{More details on the models used}

1. The Loayza et al. model covers 78 countries and is estimated for 1961-1999; growth is a function of transitional convergence (the initial income gap), cyclical reversion (the size of the initial output gap), structural policies (education, financial depth, trade integration, government size, infrastructure and governance), macroeconomic stabilisation (inflation, cyclical volatility, real exchange rate overvaluation, systemic financial crises), external conditions (terms of trade shocks) and time and country dummies. The advantage of the model is the separation of the effects of structural and macroeconomic parameters from cyclical and convergence effects.

2. A simulation exercise was conducted to compare Mexico with 20 other economies over 1981-1999. The original model is generally good for Mexico, although it doesn't fully pick up the effects of the financial crises. The fit of the model was improved by modifying the original data for financial crises and the lag on the initial output gap for Mexico, which affects the size of macro-economic stabilisation policies. Both the original estimates and those that incorporate greater financial crisis effects are given in the main text to provide a range for the importance of macroeconomic stabilisation policies. An analysis of the fit of the model for Mexico revealed that, while the fit is generally good, Mexico's growth appeared to be over-estimated in the 1986-1990 and 1991-1995 periods and underestimated from 1996-2000. This appears to arise from an incorrect lag on the output gap that underestimates cyclical reversion effects in 1996-1999 and data inputs that do not fully capture the length of the 1980s debt crisis or the severity of the 1995 Tequila crisis. This is unsurprising as financial crises are mostly idiosyncratic and it is hard to generate a series that will adequately measure all crises across all countries. The lag length on the output gap and financial crises data were calibrated to better measure the effects of these events. For example, the model predicts Mexican growth between 1991-1994 well, but not for 1995 because the size of the financial crisis effect implied by the original data (the clear driver of the fall in growth in 1995) is not large enough. The financial crisis data is calibrated so that it captures the difference between growth predicted by other factors plus the average equation error for 1991-1994 and actual growth. These changes improve the fit of the model and its power of the gap between Mexican and the others in the sample, and has more intuitive signs. Changing the data inputs for financial crises affects the importance of stabilisation policies. In the extreme, stronger financial crises effects than originally incorporated in the model may explain the remainder of the gap between the model's and actual growth for Mexico in these periods and the effect of stabilisation policies will increase in parallel.

3. The original model data was extended to the 2000-07 period for the macroeconomic stabilisation variables (CPI, the standard deviation of the output gap, real effective exchange rate overvaluation and the frequency of systemic banking crises for Mexico and the high-income, fast growing OECD countries (United States, United Kingdom, Ireland, Finland and Spain) using the OECD Analytical database. The exchange rate overvaluation index was extended by applying the rate of change in the average real effective exchange between the 1996-99 and 2000-07 periods to the original 1996-99 index level. 
4. Sala-i-Martin (1997) uses a panel of 134 countries for the period 1960-1992 and tests 62 variables identified previously in the growth literature as significant in at least one growth regression. Using 2 million regressions to test the robustness of the variables to the inclusion of others, the paper identifies 21 which appear to have a stronger relationship with growth, defined as the average growth rate of GDP per capita 1960-1992 i.e. variables with high sign certainty probabilities (i.e. a high proportion of the coefficient estimates fall on the same side of zero). The paper obtains a density of coefficient estimates of the effect on growth for each variable using regressions with different additional variables included. The author defines the strength of the relationship between growth and the explanatory variables in terms of the proportion of the density of the coefficient estimates that is either to the right or left of zero, i.e., for variable 1 , if $95 \%$ of the density of $\beta 1$ estimates lies to the right of zero and only $52 \%$ of the density for $\beta 2$ estimates for variable 2 lies to the right of zero, then variable 1 is regarded as having a stronger relationship with growth than variable 2. Estimates of the coefficients of the effect of these 21 variables, combined with the original dataset are used to identify the variables and including policy ones that appear to explain the greater part of the growth difference between Mexico and faster growing countries. Mexico is compared to 2 groups, the 10 fastest growing countries over the period and the OECD countries growing faster over the period.

5. Sala-i-Martin, Doppelhoffer and Miller (2004) use a model-averaging technique to determine which of 67 variables have the strongest relationship with growth in GDP per capita from 1960-1996. Variables are selected on the probability of regressions that contain this variable given the data. In particular, the authors estimate approximately 89 million OLS regressions where the variables are tested with combinations of other explanatory variables. Variables are selected on the basis of the sum of the probabilities given the data of regressions that include that variable (the inclusion probability). This process identifies 21 variables that are "significantly" related to growth i.e. variables with the highest inclusion probabilities and high sign certainty probabilities. Again estimates of the linear marginal effect of each of these 21 variables are used to discover which of these variables appear to be mainly responsible for the difference between Mexico's growth and that of the fastest 10 growing countries in the sample from 1960-1996 and the faster growing OECD countries. Most of these variables are either initial conditions, fixed regional effects or represent factors that are not easily influenced if at all by economic policy. 
ECO/WKP(2009)74

\section{WORKING PAPERS}

The full series of Economics Department Working Papers can be consulted at www.oecd.org/eco/workingpapers/

732. Achieving higher performance: Enhancing spending efficiency in health and education in Mexico (October 2009) Cyrille Schwellnus

731. Russia's long and winding road to a more efficient and resilient banking sector (October 2009) Geoff Barnard

730. How do institutions affect structural unemployment in times of crises?

(October 2009) Davide Furceri and Annabelle Mourougane

729. Understanding the world trade collapse

(October 2009) Calista Cheung and Stéphanie Guichard

728. Estonia and euro adoption: Small country challenges of joining EMU

(October 2009) Zuzana Brixiova, Margaret H. Morgan and Andreas Wörgötter

727 Towards better schools and more equal opportunities for learning in Italy (June 2009) Romina Boarini

726. Iceland: Challenging Times for Monetary and Fiscal Policies (August 2009) Andrea De Michelis

725. Iceland: The Financial and Economic Crisis (August 2009) David Carey

724. The role of transparency in the conduct of monetary policy (September 2009) Makoto Minegishi and Boris Cournède

723. Raising education outcomes in Greece (September 2009) Vassiliki Koutsogeorgopoulou

722. Improving the performance of the public health care system in Greece (September 2009) Charalampos Economou and Claude Giorno

721. Is there a case for price-level targeting?

(August 2009) Boris Cournède and Diego Moccero

720. The challenge of restoring French competitiveness (August 2009) Rafal Kierzenkowski

719. Improving the functioning of the Slovenian labour market (August 2009) Isabell Koske

718. What drives sovereign risk premiums? An analysis of recent evidence from the Euro Area (July 2009) David Haugh, Patrice Ollivaud, and David Turner 
717. The English National Health Service: an economic health check (July 2009) Peter Smith and Maria Goddard

716. Financial stability in the United Kingdom: Banking on prudence (July 2009) Philip Davis

715. Economic growth and the role of taxation- disaggregate data (July 2009) Gareth D. Myles

714. Economic growth and the role of taxation - Aggregate data (July 2009) Gareth D. Myles

713. Economic growth and the role of taxation - Theory (July 2009) Gareth D. Myles

712. The effectiveness of education and health spending among Brazilian municipalities (July 2009) Luiz de Mello and Mauro Pisu

711. The bank lending channel of monetary transmission in Brazil: A VECM approach (July 2009) Luiz de Mello and Mauro Pisu

710. How does decentralised minimum-wage setting affect unemployment and informality? The case of Indonesia (July 2009) Margherita Comola and Luiz de Mello

709. Intergenerational social mobility in European OECD countries (July 2009) Orsetta Causa, Sophie Dantan and Åsa Johansson

708. Equity in student achievement across OECD countries: an investigation of the role of policies (July 2009) Orsetta Causa and Catherine Chapuis

707. Intergenerational social mobility (July 2009) Orsetta Causa and Åsa Johansson

706. Taxes or grants: what revenue source for sub-central governments? (July 2009) Hansjörg Blöchliger and Oliver Petzold

705. The spending power of sub-central governments: a pilot study (July 2009) Steffen Bach, Hansjörg Blöchliger and Dominik Wallau

704. Price and volume elasticities of Brazilian foreign trade: A profit function approach (July 2009) Luiz de Mello and Mauro Pisu

703. Current account sustainability in Brazil: A non linear approach (July 2009) Luiz de Mello and Matteo Mogliani

702. The incentives to participate in and the stability of international climate coalitions: a game-theoretic approach using the WITCH Model (July 2009) Valentina Bosetti, Carlo Carraro, Enrica De Cian, Romain Duval, Emanuele Massetti and Massimo Tavoni 